\title{
Industrial Production and Capacity Utilization: Recent Developments and the 1999 Revision
}

Charles Gilbert, Norman Morin, and Richard Raddock, of the Board's Division of Research and Statistics, prepared this article. Matt Wilson provided research assistance.

In late 1999, the Federal Reserve published revised measures of industrial production (IP), capacity, and capacity utilization for the period January 1992 through October 1999. The production index for the third quarter of 1999 is now at 137.7 percent of output in 1992, compared with 135.2 percent reported before the annual revision, and the capacity index is 170.7 percent of output in 1992, compared with 167.9 percent reported previously. The rate of industrial capacity utilization - the ratio of production to capacity-was revised up 0.1 percentage point, to 80.7 percent for the third quarter of 1999. See chart 1. (Summary data as of January 14, 2000, for total industry and manufacturing are shown in appendix tables A.1 and A.2.)

Total industrial output increased at an annual rate of 4.5 percent, on average, over 1995-99. The output

Note. Other contributors to the revision and this article include the following: Ana Aizcorbe, Cynthia Bansak, William Cleveland, Carol Corrado, Mark Doms, Maura Doyle, Marcello Estevão, Gloria Fennell, Meredith Krug, Marc Lanoue, Susan Polatz, and Dixon Tranum. of computers, semiconductors, and communications equipment accounted for more than half the growth. The rate of increase in the output and capacity of these industries is now estimated to have been more rapid than previously shown, especially in 1998. Apart from computers and semiconductors, industrial production increased about 2 percent annually over the period, with little change in 1998 and a gain of 1.8 percent in 1999 (table A.3).

The updated measures reflect both the incorporation of newly available, more comprehensive source data typical of annual revisions and the introduction of improved methods for compiling a few series. The new source data are for recent years, primarily from 1997 on, and the modified methods affect data beginning in 1992. In addition, the supplementary series on the gross value of products are now expressed in 1996 dollars; these series begin in 1977.

The updated IP measures included annual data from selected editions of the 1998 Current Industrial Reports of the Bureau of the Census and available preliminary data for about 15 percent of manufacturing from the 1997 Census of Manufactures. Annual data from the U.S. Geological Survey on metallic and nonmetallic minerals (except fuels) for 1997 and 1998 were also introduced. The updating included revisions to the monthly indicator for each industry

1. Industrial production, capacity, and utilization

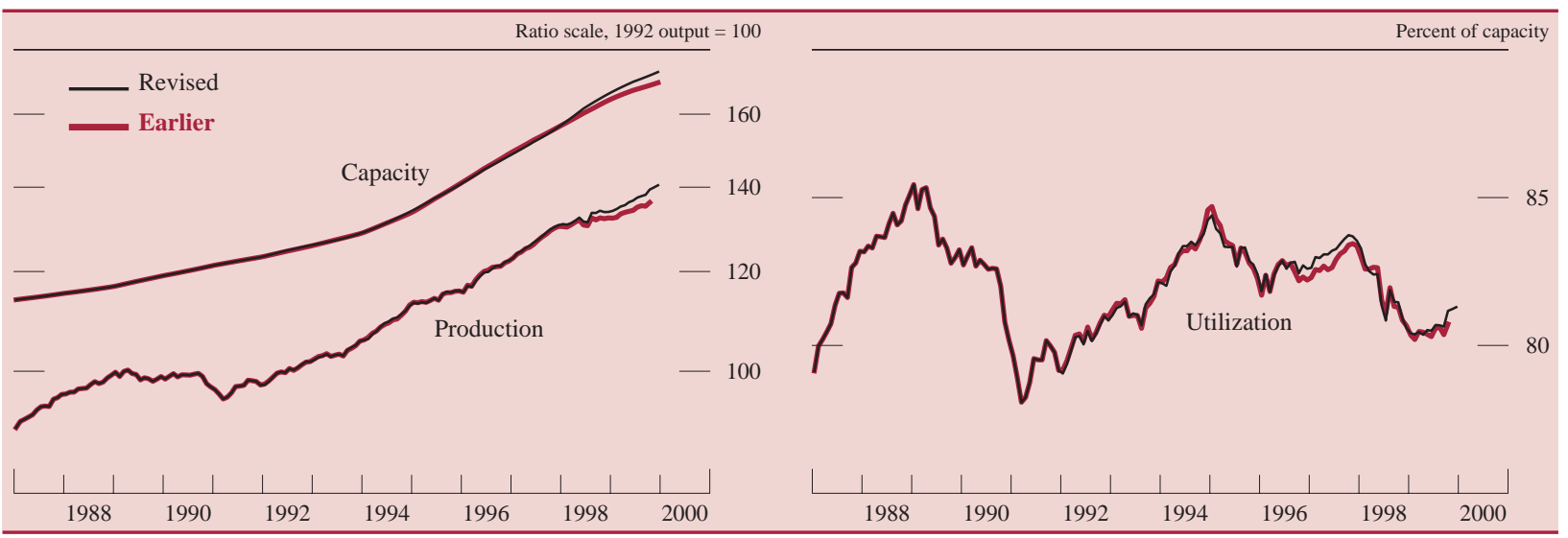

Note. The production indexes and utilization rates are seasonally adjusted. All the revised measures extend through December 1999; the earlier measures extend through October 1999. 
(physical product data, production-worker hours, or electric power usage) and revised seasonal factors.

The revision introduced improved methods for measuring the production of computer and office equipment and of motor vehicles. The new monthly production measure for computers is derived from detailed information on the major products produced by the industry. The new measures of motor vehicle production incorporate price weights for the different models of light vehicles; previously, all models of autos were weighted equally and all light trucks were weighted equally in compiling an aggregate figure, which was eventually benchmarked to comprehensive Census data.

The updated capacity and capacity utilization measures incorporated preliminary data on industry utilization rates from the 1998 Survey of Plant Capacity of the Bureau of the Census, which covers manufacturing. Also included were updated data on capacity, expressed in physical units, from the U.S. Geological Survey, the Department of Energy, and other organizations.

The Survey of Plant Capacity is the source of utilization rates for most manufacturing industries. The preliminary results of the 1998 survey, which provided industry utilization rates for the fourth quar- ter of the year, suggested that manufacturing utilization rates were generally in line with previous Federal Reserve estimates. However, dividing the upwardly revised industrial production indexes for the computer, semiconductor, and communications equipment industries by the Census utilization rates yielded a noticeable upward revision of capacity in those industries.

The capacity utilization rate for mining was revised very little; the rate of utilization in electric utilities was revised downward by 1.5 percentage points for the third quarter of 1999.

\section{PRODUCTION BY MARKET GROUPS}

The rate of increase of industrial production accelerated in 1996 and 1997 and then slowed between 1998:Q1 and 1999:Q1 (table A.1). The slowing reflected the effects of the economic turmoil in Asia on a number of industries, particularly within business equipment, nondurable consumer goods, and materials (chart 2). As Asian economies began to recover in 1999, the economic outlook for some of the weakened U.S. industries brightened as well.

Among major market groups, the revised production index for consumer durable goods has advanced

2. Industrial production, market groups, 1989-99

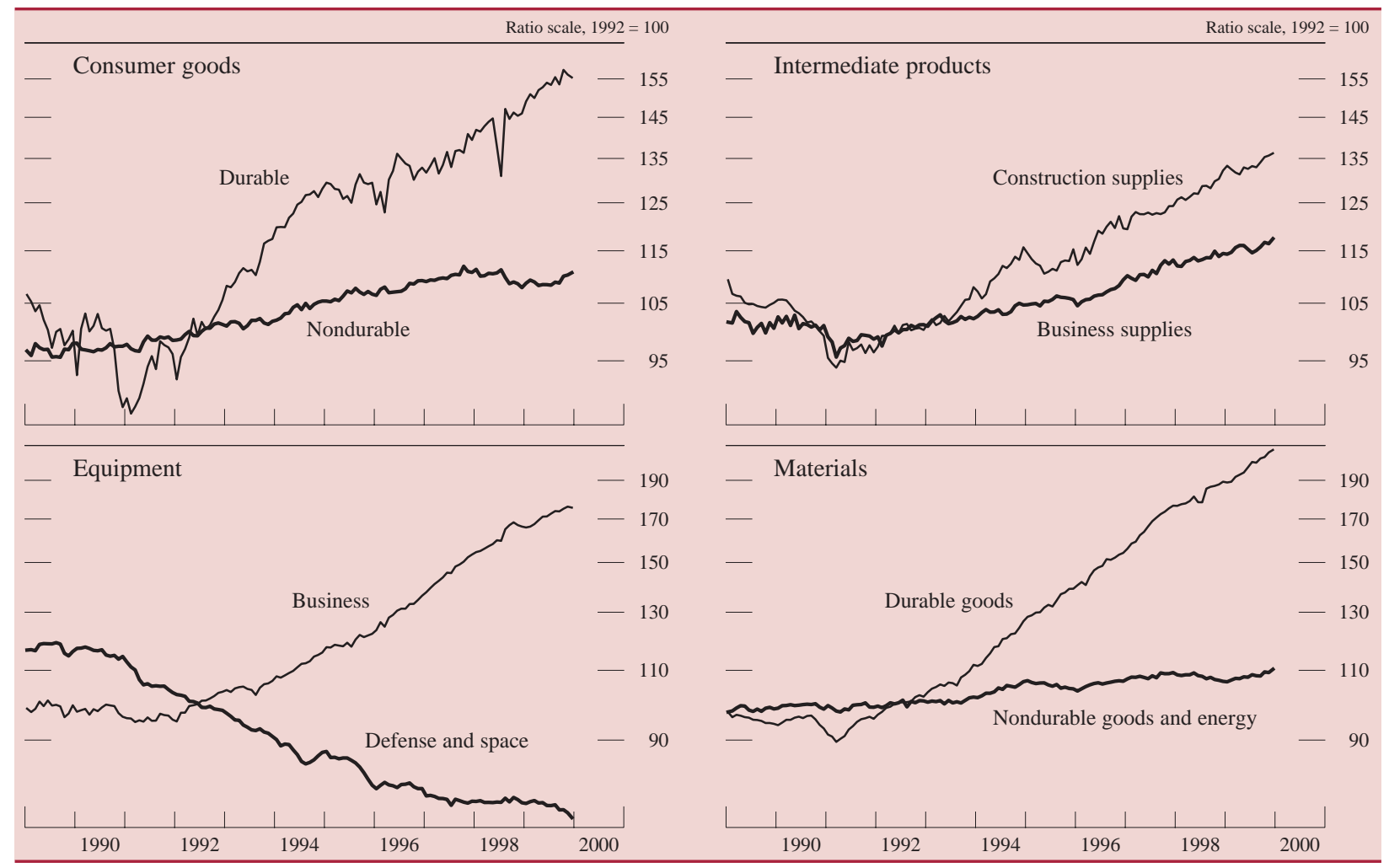


strongly in recent years, as the low rate of unemployment and rising income have bolstered the demand for consumer goods. The index, which had risen at an annual rate of 5 percent or more during 1997 and 1998, rose at an annual rate of 7.2 percent in 1999. During 1999, the output of automotive products, especially light trucks, continued upward from the high level at the end of 1998. At the same time, the series for household appliances fluctuated at a high level, and the series for carpeting and furniture, on balance, moved upward. After a pause in mid-1997, the production of home electronics, including computers, surged upward at an annual rate of about 45 percent.

The nondurable consumer goods group, which experienced a broadly based decline in the second half of 1998, stabilized in 1999 as an increase in the output of consumer energy products offset ongoing weakness elsewhere. Producers of cigarettes, clothing, and paper products suffered setbacks in the past two years; in addition, the output of consumer chemicals increased slowly, on balance, after strong gains in 1995-97. Despite a weak performance for the year as a whole, the production of some non-energy nondurable consumer goods, including consumer chemicals, picked up noticeably in the fourth quarter of 1999.

The output of business equipment has been boosted by gains in the output of business computers and office equipment that averaged more than 50 percent per year from 1996 on. This market group's increases slowed in 1999 because of declines in the output of industrial equipment, farm equipment, and transit equipment, particularly railroad equipment and commercial aircraft and ships. The production of defense and space equipment resumed its decline in 1999 after an uptick in 1998.

After having risen more slowly in 1997, the output of construction supplies accelerated in 1998 and early 1999, when it was lifted to an elevated level by strong demand for housing and by unusually mild weather, and then flattened in mid-1999. The output of industrial materials slowed in 1998, as increased import competition and decreased foreign demand resulting from the Asian economic crisis reduced output of internationally traded commodities such as steel, paper, and chemicals. Output picked up again in 1999. In contrast, the output of durable materials, which include the fast-growing series for computer parts and semiconductors, advanced 7.3 percent in 1998 and 9.3 percent in 1999 . With a solid rebound in the production of chemical and paper materials, the output of nondurable materials, after having declined in 1998, increased 4.9 percent in 1999. The output of energy materials fell about 1 percent in 1998 and had regained only a portion of that decrease by the end of 1999 .

\section{PRODUCTION BY INDUSTRY GROUPS}

During the past five years, the growth of industrial production continued to be concentrated in durable manufacturing, which advanced 11.4 percent in 1997 before gradually easing to 7.0 percent in 1999 (table A.4). The relatively strong expansion in this sector has been supported by the sustained rapid increases in the output of computers, semiconductors and related electronic components, and communications equipment. Production in these high-technology industries increased, on average, approximately 40 percent per year from 1995 to 1999 . The output of other manufacturing industries was unchanged over the four quarters of 1998 and then edged up in 1999. In 1998, the economic troubles in Asia reduced, either through higher import volume or lower export volume, the domestic production of iron and steel, some chemicals, and other internationally traded goods. Although many of these industries began to recover last year, the production of civilian aircraft, which had been a source of strength, declined from late 1998 on. Production in mining and utilities eased in 1998 but showed less weakness in 1999.

\section{CAPACITY AND CAPACITY UTILIZATION}

The annual rate of capacity growth in manufacturing, which averaged 6.1 percent per year in 1996 and 1997, accelerated to 7.0 percent in 1998 and then eased to 4.7 percent in 1999 (table A.5). The most rapid expansions of capacity and the upward revisions of earlier estimates were again concentrated in durable manufacturing, especially in the computer, communications equipment, and semiconductor industries. The capacity increase in these industries averaged more than 40 percent per year over 1995-99. The rest of the manufacturing sector increased capacity approximately $22 / 3$ percent in 1995 and 1996, 3 percent in 1997 and 1998, and 11/3 percent in 1999. The capacity expansion in mining and utilities was slower; in particular, the capacity in oil and gas extraction and metal mining declined in 1999, whereas that for utilities increased 1.4 percent. The North American Electric Reliability Council still projects increases in capacity that will fall short of probable increases in demand.

The rate of manufacturing capacity utilizationthe ratio of output to capacity—was revised up 
0.1 percentage point in the fourth quarter of 1998 and 0.3 percentage point in the third quarter of 1999 (table A.6). Utilization in manufacturing in the fourth quarter of 1999 was 80.3 percent, a level 0.8 percentage point lower than the 1967-98 average. The rates in both primary- and advanced-processing industries fell a few percentage points from the fourth quarter of 1997 to the fourth quarter of 1999.

Utilization in mining fell substantially in 1998 and 1999 because of declines in oil and gas well drilling and in metal mining. In the fourth quarter, utilization rates in mining and gas utilities were at belowaverage levels; in contrast, the rate of utilization in electric utilities was 95.8 percent, still a high level.

\section{TECHNICAL ASPECTS OF THE ANNUAL REVISION}

The revision incorporated the updating of the comprehensive annual data and of the revised monthly source data used in the estimation of production, capacity, and utilization. More-up-to-date results were obtained from the 1997 Census of Manufactures, the 1998 Survey of Plant Capacity, other annual industry reports, recent information on prices, and revised monthly source data on physical products and on labor and electricity inputs. ${ }^{1}$ In addition, the methods for estimating output for several industries were changed; however, the changes in structure in IP leave the number of individual series at 267. Along with the individual production series and seasonal factors, the annual value-added weights used in aggregating the indexes to market and industry groups were updated. (See box "Data Availability.")

\section{Changes to Individual Production Series}

\section{Computers}

This revision includes a new method for estimating computer production. The index of the computer and office equipment industry (SIC 357) continues to be based on the aggregate of three components: office and computing equipment for business (in the market group for business equipment), office and computing

1. Information about the sources of monthly data used to calculate the indexes can be found in table 1 in "Industry structure of industrial production: classification, value-added weights, and description of series" on the Board's web site (http://www.federalreserve.gov/g17/ About.htm).

\section{Data Availability}

Files containing the revised industrial production and capacity utilization data are available on the Board's web site (www.federalreserve.gov/releases/g17) and on diskettes from Publications Services (telephone 202-4523245). The revised data are also available through the STAT-USA web site of the Department of Commerce (www.stat-usa.gov). Further information on these revisions is available from the Board's Industrial Output Section (telephone 202-452-3197).

A document with printed tables of the revised estimates of series shown in the G.17 release is available on request to the Industrial Output Section, Mail Stop 82, Division of Research and Statistics, Board of Governors of the Federal Reserve System, Washington, DC 20551.

equipment for the home (in consumer durables), and computer parts (in equipment parts within durable goods materials). However, whereas monthly input measures were previously used, quarterly data from Dataquest, covering unit sales and unit values for an average of about 450 distinct computer models in any quarter, are now used to estimate the real output of the computer industry. These new data show a faster rise in output in recent years and indicate that a larger share of output has been sold for home use than indicated by the previously published indexes.

These individual computer series are now calculated from detailed quarterly data on unit sales and unit values for three types of computers: PCs, notebook computers, and computer servers and mainframes. The IP series for home computers is developed from data on PCs and notebooks sold to consumers; for business computers the IP series is developed from data on PCs and notebooks sold to businesses and all sales of servers and mainframes. Data on overall sales of the three types of computers, regardless of the purchaser, are used to estimate the IP series for computer parts.

Each new IP index for computer production is a measure of real output computed using a current dollar estimate of production and a constant-quality price index. The nominal value of production is computed as the sum of the estimated nominal value of production of each relevant computer model destined for a specific market segment. Because the quarterly data from Dataquest cover sales and not production, the estimates of nominal production for each computer model must be derived. Annual production-sales relationships are estimated for all of the major product lines in the industry (IBM notebooks, Dell PCs, Compaq servers, and so on) by 
combining the detailed Dataquest data with the Census Bureau's microdata on domestic production of computers in its Longitudinal Research Database. These relationships, available through 1997, are extrapolated and interpolated and then applied to the quarterly data on computer sales.

The constant-quality price indexes for domestic sales of personal computers and servers and mainframes are computed as Fisher price indexes, treating each model of computer as a separate good; a producer price index from the Bureau of Labor Statistics (BLS) was used for notebook computers. The Fisher price indexes computed using the detailed Dataquest data are similar to estimates derived from "hedonic" regressions. These regressions are used to estimate the value of the different features of computers (such as CPU speed, memory, and so on), which are then used to derive a constant-quality price index for computers.

The new quarterly production index for computers (chart 3) rises considerably faster in 1998 and 1999 than previously reported. The surge in 1998 was broad-based across computer platforms. Early in 1999, the production of PCs for home use spiked when demand was spurred by rapidly falling prices. Later in the year, the production of servers increased markedly. In 1999, the expansion of computer production returned to about the same rates that prevailed from 1994 to 1997.

\section{Autos and Light Trucks}

The method for deriving the output of autos and light trucks (SIC 3711 pt., 3 pt.) was improved to capture in a more timely way shifts in the product mix and relative values. Before this revision, the production indexes for autos and for light trucks were calculated from simple counts of units assembled, and an aggregate index was benchmarked to comprehensive output measures derived from data in the Census of Manufactures and the Annual Survey of Manufactures. In this procedure, variations in relative values, resulting at least in part from shifts in the product mix, were often captured only during the annual revision process.

In this revision, the IP indexes for autos and light trucks from 1992 forward are computed as annually weighted Fisher quantity indexes; the calculations use data for each vehicle model that include the number of units assembled monthly and the list price at the start of the new model year. Compared with the previous index, the revised index shows the output of autos to have increased more slowly and the produc-
3. Growth in computer output, 1996-99

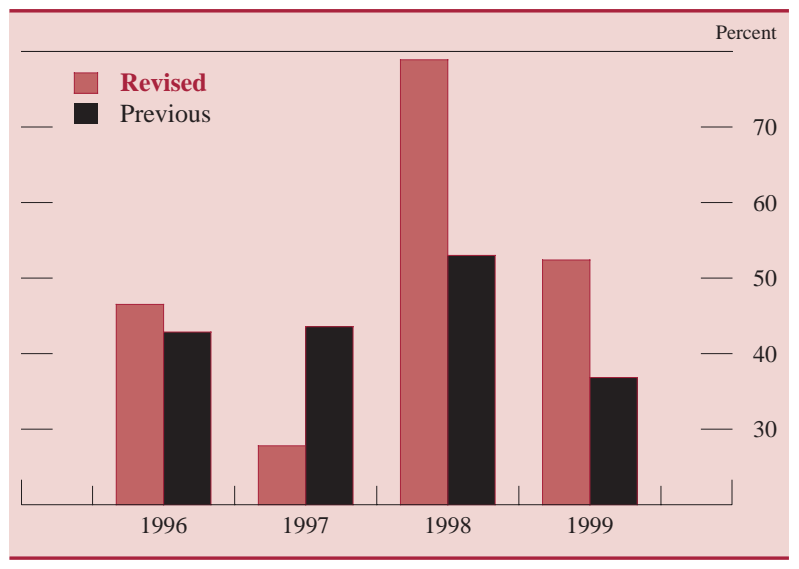

NoTE. Data are fourth quarter to fourth quarter. The growth for the previous series in 1999 is measured (annualized basis) from 1998:Q4 to October 1999.

tion of light trucks to have risen more rapidly over 1992-99. These revisions reflect the changes in the product mix that have occurred in the 1990s. In particular, the production and demand for light trucks, especially expensive sport-utility vehicles, skyrocketed over this period, resulting in a pronounced shift in the product composition and in the relative prices of light vehicles. These revisions to the indexes for autos and light trucks were largely offsetting, so the aggregate indexes were little changed.

\section{Changes in Other Series}

The monthly indicators for four other series have changed in this revision. Beginning with data for 1992, the series on bolts and fasteners (SIC 345) and on metalworking machinery (SIC 354) use production-worker hours in the respective industry as a monthly indicator; previously, the series had been based on electric power consumption. Effective in 1997, the monthly indicators for railroad equipment (SIC 374) and for flat glass (SIC 321) are also production-worker hours; previously, they were based on quarterly physical product data that are no longer collected. (See box "Source Data in Monthly IP.")

\section{New Annual Data}

This annual revision incorporated a smaller increment of new annual data than is usual for an annual revision. A typical revision includes new comprehensive annual source data on the output of all manufacturing industries as well as on the output of the metal mining and nonmetallic minerals industries. In this 


\section{Source Data in Monthly IP}

The source data for the industrial production index for a month become available over several months (see table). After the first estimate for a month is published-about 15 days after the end of the relevant month - the data are subject to revision for the next three months. The gradual availability of source data accounts for the series of revisions. The major types of source data for the industrial production index are physical product data, production-worker hour data, and electric power use data.

The first estimate of IP for a month includes data on both physical product measures of output (20 percent of the overall index in 1999) and production-worker hours (28 percent of the index). Electric power use data and additional physical product data become available for the second estimate of IP for a month; with this first revision to a month, source data are unavailable only for about 15 percent of IP. Additional monthly and quarterly physical product data become available during the next two months, bringing the physical product content of IP up to 43 percent by the fourth estimate for the month and to 45 percent after an annual revision.

Proportion of industrial production covered by data available in successive monthly estimates, 1999

Percent

\begin{tabular}{c|r|c|c|c}
\hline \multirow{2}{*}{ Type of data } & \multicolumn{4}{|c}{ Month of estimate } \\
\cline { 2 - 5 } & 1 st & 2nd & 3rd & 4th \\
\hline Physical product .............. & $20^{1}$ & 31 & $42^{2}$ & 43 \\
Production-worker hours ........ & $28^{3}$ & 28 & 28 & 28 \\
Electric power use ............ & 0 & 26 & 26 & 26 \\
Federal Reserve estimates $4 \ldots \ldots$ & 53 & 15 & 4 & 35 \\
Total industrial production ..... & $\mathbf{1 0 0}$ & $\mathbf{1 0 0}$ & $\mathbf{1 0 0}$ & $\mathbf{1 0 0}$ \\
\hline
\end{tabular}

1. Includes provisional series totaling nearly 13 percent of IP that are derived from weekly data and for which the actual data may lag several months.

2. Includes quarterly data totaling 6 percent of IP that, on average, are received for the third estimate of industrial production. Specifically, data are available for the second estimate of the last month of a quarter, the third estimate of the second month of a quarter, and the fourth estimate of the first month of a quarter.

3. This figure refers only to those individual series that both initially and ultimately are based on the hours data.

4. Estimates for series not yet covered by data for physical product, production-worker hours, or electric power use.

5. Includes monthly and quarterly physical product data totaling 2 percent of IP that typically are available too late for inclusion in the current index.

annual revision, however, additional annual observations were available for only a small number of manufacturing industries because results from the 1997 Census of Manufactures were available for only a portion of manufacturing. In addition, because the primary establishment classification system used by the Census of Manufactures was the new North
American Industrial Classification System (NAICS) and data classified by the U.S. Standard Industrial Classification (SIC) were an auxiliary product, the new data covered only about 15 percent of the IP series. A full set of 1997 annual indexes, as well as partial results for 1998, should be incorporated in the annual revision published this year. The Federal Reserve plans to issue IP indexes grouped on a NAICS basis in late 2001.

\section{Weights}

The IP index is an annually weighted Fisher index. ${ }^{2}$ The weights are expressed as annual unit value added, that is, value added (an annual series in dollars) divided by an IP index for the year. In this revision, the annual value-added data were updated if available (table A.7). For the period after the latest available value-added data, the unit-value-added figures were estimated from available data on producer prices through the most recent year and then extrapolated for the following year.

The available reports from the 1997 Census of Manufactures as well as revenue and expense data reported by the Department of Energy and the American Gas Association provided industry value-added data for selected manufacturing industries and utilities through 1997. The latest value-added data for mining come from selected reports from the Census of Mineral Industries for 1997; otherwise, the 1992 Census was the source.

\section{Revised Monthly and Quarterly Data}

The monthly and quarterly physical product data that are used to measure the high-frequency movements of many IP indexes were updated to capture data that became available after the close of the regular four-month reporting window. Monthly data on production-worker hours or sales of electric power in kilowatt-hours to industry groups, along with estimates of trends in output per worker-hour or kilowatthour, are used to indicate the monthly change in output for many individual IP indexes. The Bureau of Labor Statistics benchmark of the employment data for March 1998 was incorporated in this revision.

2. The aggregation procedures are described by Carol Corrado, Charles Gilbert, and Richard Raddock in "Industrial Production and Capacity Utilization: Historical Revision and Recent Developments," Federal Reserve Bulletin, vol. 83 (February 1997), pp. 67-92. 
Revised data on the sales of electricity to industries since 1992 were incorporated as well. Because of offsetting revisions among the component series, through 1997 the annual revisions of the growth of total electric power use were generally small; compared with the pre-revision estimates, electric power use now decreases more in 1998 and falls less rapidly in 1999 (table A.8). ${ }^{3}$

The largest effect of these changes on IP resulted from the incorporation of new data on semiconductor output and prices for 1998. Compared with the previous estimate, the real output of the semiconductor industry is now shown to have risen nearly twice as fast in 1998 and almost one-third faster in 1999. The measure of real output of semiconductors is derived from an estimate of the nominal value of U.S. production and a price index. ${ }^{4}$ The revisions to output result primarily from the incorporation of quarterly price data for 1998 for two important types of devices: memory chips and computational microprocessors. These price indexes are calculated once a year when detailed quarterly data for the previous year become available. In the meantime, these price indexes are estimates based on producer price indexes for these devices from the BLS. ${ }^{5}$

\section{Measurement of Capacity}

The revisions to capacity and utilization incorporated the revised production indexes, the preliminary results of the 1998 Survey of Plant Capacity, and updated measures of capacity in physical units for selected industries. In addition, improvements in the capital input measures and in the models used to estimate manufacturing capacity were introduced. The new capital flows table for 1992 of the Bureau of Economic Analysis was incorporated into our estimates of capital input. ${ }^{6}$ The improved specification of

3. Seasonal factors for the electric power series have been reestimated by using data through April 1999. Seasonal factors for worker hours were based on data through October 1999. Factors for the monthly physical product series were based on data through June or later in the summer.

4. The data for the individual devices are aggregated using Fisher aggregation methods. See "Industrial Production and Capacity Utilization: Historical Revision and Recent Developments" for a general description of the methodology.

5. Additionally, the price index for semiconductors was expanded to include information available beginning in 1996 on embedded microprocessors. The market for embedded microprocessors-chips for noncomputer applications, such as cars, video games, and network routers - is relatively small, but it is one of the most rapidly expanding segments of the semiconductor industry.

6. A capital flows table shows the asset composition of each industry's capital spending. See Michael Mohr and Charles Gilbert, "Capi- the models better captures advances in technology that are "embodied" in capital goods. In addition, the procedures for estimating capacity series for light vehicles and semiconductors were modified.

\section{Capacity Estimation Procedure}

The Federal Reserve Board's capacity indexes attempt to capture the concept of sustainable maximum output - the greatest level of output a plant can maintain within the framework of a realistic work schedule after factoring in normal downtime and assuming sufficient availability of inputs to operate the capital in place. The concept itself generally conforms to that of a full-input point on a production function, with the qualification that capacity represents a sustainable maximum rather than some higher unsustainable short-term maximum. Capacity estimates for most manufacturing industries are based on responses to the Survey of Plant Capacity (SPC), conducted by the Census Bureau and partially funded by the Federal Reserve. These industries account for a little less than 80 percent of total industrial capacity. Capacity and output data reported in physical units from government and trade sources are available for portions of several industries within manufacturing (paper, industrial chemicals, petroleum refining, primary metals, and motor vehicles) as well as for electric utilities and a portion of mining. In the absence of utilization data for some mining series, capacity is based on trends through peaks in production. Overall, capacity indexes are constructed for seventy-eight detailed industries (fifty-five in manufacturing, twenty-one in mining, and two in utilities), which mostly correspond to industries at the two- and three-digit SIC level.

Six general steps are involved in calculating the utilization rates published by the Federal Reserve.

Step 1. Implied capacity indexes $\left(I C A P_{t}\right)$ are constructed by dividing a production index $\left(I P_{t}\right)$ by a utilization rate $\left(U_{t}\right)$ for an end-of-year period: $I C A P_{t}=I P_{t} / U_{t}$. For industries whose capacity indexes are based on the SPC, the calculation is done using fourth-quarter data; for other industries, the calculation typically uses December data. These indexes are expressed, like the industrial production indexes, as a

tal Stock Estimates for Manufacturing Industries: Methods and Data,' 1996 (http://www.federalreserve.gov/releases/g17/capital_stock_doclatest.pdf). 
percentage of production in a base year, currently $1992 .^{7}$

Revisions to the implied capacity indexes can arise from either revisions to the industrial production index or to the utilization rates. For example, in this revision, the production index for computers (SIC 357) displays faster growth because of an improvement in the methodology for measuring computer output. Consequently, the capacity index for computers required a similar revision. The revised implied capacity index $\left(I P_{t} / U_{t}\right)$ fully incorporates the revisions to production and the new data on utilization rates.

Step 2. The implied capacity indexes are related to alternative indicators of capacity growth in a regression model. The Federal Reserve's estimates of annual capacity growth at the most detailed level are derived from the fitted values of the regression models that relate the implied capacity indexes to these alternative indicators; in general, the regressions are designed to improve the year-to-year changes in the implied capacities but to leave their trends intact.

For some industries, the alternative indicators include the physical capacity measures and time trends. These regressions essentially re-trend the physical capacity estimates to the trend growth path of the preliminary implied capacity indexes. For industries whose capacity indexes are based on the SPC, the alternative measures of capacity include estimates of industry capital input; trends; occasional dummy variables for level shifts, outliers, or trend breaks; and variables related to the average age of the capital stock. ${ }^{8}$ (See box "Modeling Capacity with Utilization Rates from the Survey of Plant Capacity" for more detail.)

For industries whose capacity indexes are based on the SPC, the alternative indicators, such as the capital measures derived from investment data, come from surveys other than the SPC. They should be uncorrelated with the sampling errors for the utilization rates, which would then not be present in the fitted values for the models. The differences between published Federal Reserve capacity measures and implied capacity indexes from the SPC are not predictable

7. For example, if the production index in the fourth quarter of 1999 is 150 ( 150 percent of the average of 1992 production) and the related utilization rate is 80 percent, the implied capacity index is $150 / 0.8=187.5$.

8. In the Survey of Plant Capacity, the definitions of capacity have changed somewhat over time. For the 1974-88 period, the utilization rates based on the "preferred capacity" definition are used to construct the implied capacity indexes; for 1989 to the present, those based on the "full production" definition are used. from measures of cyclical variation in the overall economy or industry-specific cyclical variation. The differences are, however, correlated with past differences for many industries. The implication is that, generally, the regression procedure smooths through correlated noise without discarding useful SPC information.

The final annual growth rates for the individual FRB capacity series are generally equal to the growth rates for these baseline capacity estimates. The remaining steps translate the baseline estimates into the final monthly individual and aggregate FRB series on capacity and utilization.

Step 3. A monthly time series is formed by interpolating between the fourth-quarter baseline capacity indexes produced by the regression models. A new interpolation procedure, which was introduced in March 1999, allowed capacity growth rates to change smoothly over time; with this revision, the monthly data for 1992 on were reestimated using the new procedure. Previously, monthly capacity figures were computed based on the assumption of a constant growth rate of capacity throughout a year, with potentially abrupt changes in growth rates between the last months of one year and the first months of the next. At the most detailed industry level, the new capacity estimates maintain the same growth rates from fourth quarter to fourth quarter that were calculated under the previous procedure.

Step 4. An adjustment may then be applied to remove capacity that accommodates seasonal swings in output. This adjustment is prominent in the capacity index for electric utility generation, in which the margin for summer peak loads is removed from the equipment's rated capacity.

An adjustment may also be applied to retain consistency with historical utilization levels based on the McGraw-Hill/DRI survey, which was the primary source of the level of utilization rates from 1954 through the mid-1970s. Generally, utilization rates from the Census survey, now the main source for manufacturing utilization rates, were lower, on average, than those of the discontinued McGraw-Hill/ DRI survey for the fourteen years they overlapped; thus, to maintain continuity, the Federal Reserve utilization rates for major industry totals and subtotals differ from those issued by the Census Bureau.

Step 5. The monthly capacity aggregates are constructed in three steps: (1) total value added for the aggregate is divided by the sum of the component capacities weighted by unit value added to calculate 


\section{Modeling Capacity with Utilization Rates from the Survey of Plant Capacity}

Capacity indexes for industries that account for nearly 80 percent of total industrial capacity are based on regressions using results from the Survey of Plant Capacity (SPC). The capacity model for an industry relates its implied capacity index $\left(I C A P_{t}\right)$, constructed by dividing the Federal Reserve production index for that industry by the time series of the Survey of Plant Capacity utilization rates, to deterministic trends $(t)$, measures of industry capital input $\left(K_{t}\right)$, variables that capture the age profile of the capital stock $\left(A_{t}\right)$, and various dummy variables (the $D_{i, t}$ ). The natural logarithms of the variables are modeled as

$$
\begin{aligned}
\log \left(I C A P_{t}\right)= & a_{0}+a_{1} t+b_{1} \log \left(K_{t}\right)+c_{1} \log \left(A_{t}\right) \\
& +\sum d_{i} D_{i, t}+u_{t} .
\end{aligned}
$$

If the $\log$ of capital input is subtracted from both sides in the expression above, it can be interpreted as a model of capital productivity at capacity:

$$
\begin{aligned}
\log \left(I C A P_{t} / K_{t}\right)= & a_{0}+a_{1} t+\left(b_{1}-1\right) \log \left(K_{t}\right)+c_{1} \log \left(A_{t}\right) \\
& +\sum d_{i} D_{i, t}+u_{t} .
\end{aligned}
$$

The fitted values from the regression model are used as the baseline estimates of capacity. This procedure attempts to capture the measurable changes in capacity that are reflected in the flow of services from capital formation and in trends in capital productivity, related to, among other things, the age profile of the capital stock.

Previously, capacity was modeled such that capital productivity was a deterministic function of time and of dummy variables:

$$
\log \left(I C A P_{t} / K_{t}\right)=a_{0}+\sum a_{i} t^{i}+\sum d_{i} D_{i, t}+u_{t} .
$$

The new models relax the implicit assumption in the old models of a unit coefficient on $b_{1}$ and add the variables related to the age profile of the capital stock. Given estimates of the capital measures, these regressions provide a convenient means of estimating capacity for years beyond the most recent SPC.

The trend terms in the model attempt to capture deterministic growth in capital productivity. Additionally, dummy variables are occasionally included to account for a shift in trend or in level, or to account for an obvious outlier. Several series have a level shift dummy variable for the post-1994 period, when the sample on which the SPC is based increased about 70 percent, to between 16,000 and 17,000 plants.

The capital input measures reflect the flow of services derived from the net stocks of productive assets, which, in turn, are based on estimates of industry investment in the various asset categories. The capital input measures are developed from industry-level investment data from the Census Bureau's Annual Survey of Manufactures and Census of Manufactures; from new business investment and deflators by asset type derived from the BEA's national income and product accounts; and from the BEA's capital flows tables (CFTs), which provide a detailed breakdown of the asset composition of industry-level investment for selected years. Updating estimates of industry-level and asset investment and incorporating the most recent CFT (1992) yielded substantially stronger capital input growth than previous estimates; from 1992 to 1999, the annual average growth in capital input was revised upward about 0.8 percentage point, to 3.2 percent.

The age variable is the ratio of the age of an industry's capital stock relative to its expected service life, given the mix of assets that compose the stock. This measure, an aggregate annual utilization rate; (2) the resulting annual utilization rate is then divided into the corresponding IP aggregate to calculate an annual capacity index; and (3) the annual capacity index is interpolated using an annually weighted Fisher index of its constituent monthly capacity series to derive the monthly capacity aggregate. ${ }^{9}$ For the very recent period, since the latest full year of utilization rate data (1998 in this revision), each monthly capacity aggregate is extrapolated by this same Fisher index, adjusted by a factor that accounts for the differences in their relative growth rates.

9. More detail on the aggregation procedure is available in "Industrial Production and Capacity Utilization: Historical Revision and Recent Developments."
Step 6. Utilization rates for the individual series and aggregates are calculated by dividing the pertinent monthly production index by the related capacity index.

\section{Special Methods for Light Vehicles and Semiconductors}

Capacity estimates for autos (SIC 371 pt.) and for light trucks (SIC 371 pt.) are constructed from estimates of the peak historical assembly-line speed and the number of hours that can be worked at each plant in the United States. Annual linespeed data and the number of shifts at individual plants are reported in Ward's Automotive Reports. An annual capacity count for a plant is calculated by multiplying the peak linespeed by the hours per year that the plant could 


\section{Modeling Capacity with Utilization Rates-Continued}

expressed as a percentage, represents the portion of the aggregate life of a given mix of assets that has been used up. In several studies, age variables have been used to capture the effect of embodied technological change. ${ }^{1}$ The idea of embodiment is that productivity-augmenting

1. See, for example, Richard McHugh and Julia Lane, "The Age of Capital, the Age of Utilized Capital, and Tests of the Embodiment Hypothesis," The Review of Economics and Statistics, vol. 69 (May 1987), pp. 362-67; Richard Nelson, "Aggregate Production Functions and Medium Range Growth Projections," American Economic Review, vol. 54 (September 1964), pp. 575-606; and Michael Gort, Byong-Hong Bahk, and Richard A. Wall, "Decomposing Technical Change," Southern Economic Journal, vol. 60 (July 1993), pp. 220-34. technological change is vintage specific, that is, it is embedded in the design of new equipment and structures, rather than affecting all existing inputs in the production process. For manufacturing as a whole, the age of the capital stock in years (left panel) peaked in 1988; for the next few years, a shift in the composition of investment spending toward shorter-lived assets helped bring down the average age of the capital stock. On balance, however, the age of the stock of the individual asset classes continued to increase in the early 1990s until a surge in investment in the mid-1990s drove down the age of the capital stock relative to its expected life (right panel).

Average age of capital, 1959-99

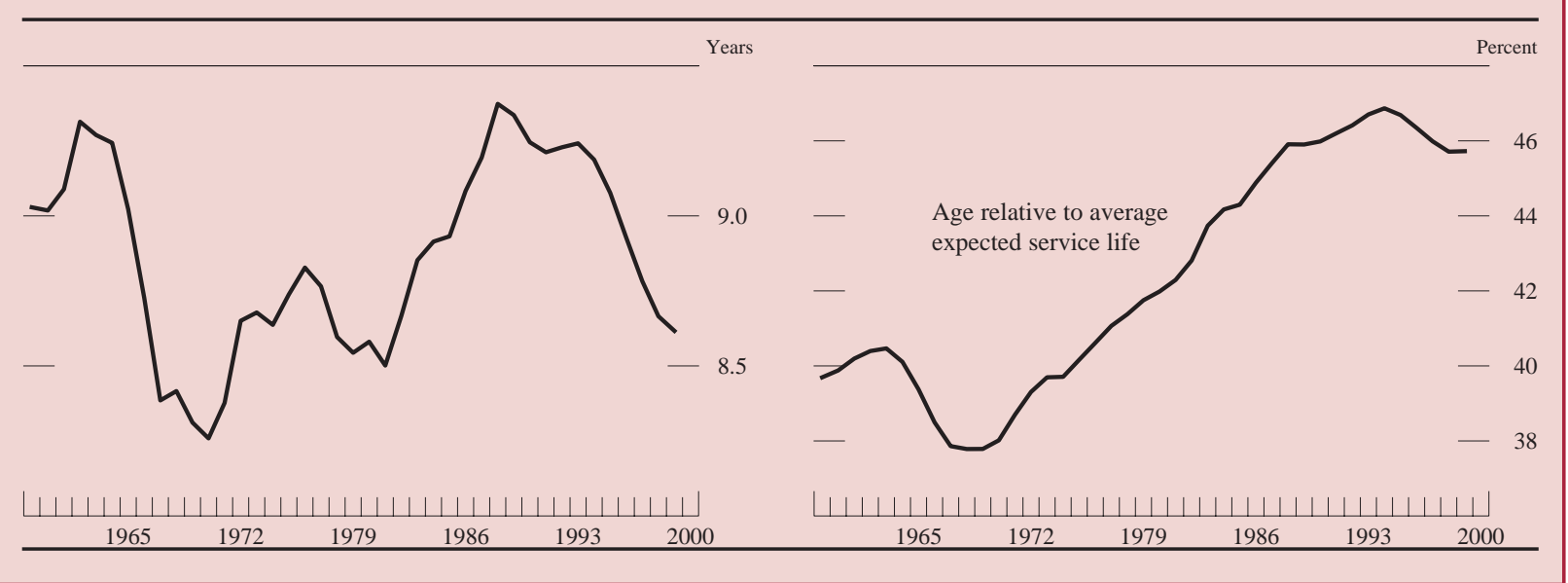

run. Before this revision, all autos and light trucks were weighted equally in compiling the aggregate figures. With this revision, the plant-level data are now aggregated using price weights for the different models of light vehicles. The method adopted in this revision better captures shifts in the composition of vehicles produced. If a plant produces multiple models on one assembly line, the model price attributed to this plant is computed as a weighted average of model prices according to estimated production levels at the plant. The new approach indicates a shift over time toward capacity of more expensive light trucks.

The capacity index for semiconductors (SIC 3674) is estimated slightly differently from the other SPCbased indexes. Semiconductors are treated differently because their IP index exhibits extraordinarily fast growth; therefore, an implied capacity index based on the IP index is difficult to model beyond using an exponential trend. The new capacity model is based on an implied capacity index constructed by dividing the number of chips produced (based on data from the Semiconductor Industry Association and the Bureau of the Census) by the SPC utilization rate. This implied capacity index, instead of the standard one computed using the IP index, is then fitted using the alternative capacity indicators, such as capital input. The fitted values from the regression are then multiplied by the ratio of semiconductor IP to the chip count. The growth of the ratio is a measure of quality change in semiconductors. 


\section{APPENDIX A: SUMMARY TABLES BASED ON THE G.17 RELEASE, JANUARY 14, 2000}

A.1. Revised data for industrial production, capacity, and utilization for total industry, 1987-99

Seasonally adjusted data except as noted

\begin{tabular}{|c|c|c|c|c|c|c|c|c|c|c|c|c|c|c|c|c|c|}
\hline \multirow{2}{*}{ Year } & \multirow{2}{*}{ Jan. } & \multirow{2}{*}{ Feb. } & \multirow{2}{*}{ Mar. } & \multirow{2}{*}{ Apr. } & \multirow{2}{*}{ May } & \multirow{2}{*}{ June } & \multirow{2}{*}{ July } & \multirow{2}{*}{ Aug. } & \multirow{2}{*}{ Sept. } & \multirow{2}{*}{ Oct. } & & & & $\mathrm{Qu}$ & arter & & nnul \\
\hline & & & & & & & & & & & Nov. & Dec. & 1 & 2 & 3 & 4 & avg. ${ }^{1}$ \\
\hline & & & & & & & Industr & al produ & tion (pe & centage & change) & & & & & & \\
\hline 1987 & -.6 & 1.2 & .4 & .4 & .4 & .9 & .6 & .1 & -.1 & 1.4 & .3 & .6 & 4.2 & 6.7 & 5.6 & 7.1 & 4.6 \\
\hline 1988 & .1 & .3 & .0 & 6 & .1 & .1 & .7 & .5 & -.4 & .3 & .8 & .5 & 3.2 & 3.1 & 3.9 & 3.6 & 4.5 \\
\hline 1989 & 6 & -8 & 9 & 2 & -.6 & -.2 & -1.0 & 4 & -.2 & -.5 & 4 & .5 & 3.8 & .5 & -4.4 & $\begin{array}{l}-.1 \\
-1\end{array}$ & 1.8 \\
\hline 1990 & -.5 & .5 & .5 & -.6 & .4 & .0 & .0 & .2 & .1 & -.6 & -1.3 & -.6 & 2.0 & .6 & 1.0 & -5.8 & -.2 \\
\hline 1991 & -.5 & -.8 & -.9 & .3 & .8 & 1.2 & .1 & .1 & 1.0 & -.1 & -.1 & -.6 & -8.3 & 1.5 & 6.2 & 1.1 & -2.0 \\
\hline 1992 & .0 & .6 & 8 & 8 & .2 & -.1 & .7 & -3 & .5 & .5 & .5 & .0 & 9 & 6.5 & 2.8 & 4.5 & 3.1 \\
\hline 1993 & .4 & .4 & $\begin{array}{l}.0 \\
.2\end{array}$ & $\begin{array}{l}.0 \\
.4\end{array}$ & $\begin{array}{r}.2 \\
-.5\end{array}$ & .3 & .1 & -.2 & 1.1 & .5 & .4 & .7 & 3.7 & 1.8 & $\begin{array}{l}2.0 \\
1.4\end{array}$ & 6.6 & 3.4 \\
\hline 1994 & 2 & .2 & 9 & .6 & .8 & 6 & .3 & .5 & 2 & .6 & 6 & 9 & 5.1 & 8.1 & 5.9 & 6.6 & 5.5 \\
\hline 1995 & 6 & -1 & 2 & -.1 & 4 & 5 & -4 & 1.2 & 4 & -1 & 3 & 0 & 5.7 & 1.6 & 3.8 & 3.0 & 4.9 \\
\hline 1996 & -.3 & 1.2 & -.2 & 1.2 & .9 & .7 & .1 & .7 & .5 & -.1 & .7 & .3 & 2.3 & 9.1 & 5.8 & 4.3 & 4.4 \\
\hline 1997 & .5 & 9 & 4 & 6 & 4 & 6 & .5 & 6 & 6 & 6 & 4 & 3 & 6.5 & 6.7 & 6.9 & 6.9 & 6.4 \\
\hline 1998 & .2 & -.1 & .3 & .4 & 6 & -.7 & -.1 & 1.8 & .0 & .4 & -.2 & .0 & 2.4 & 3.0 & 2.9 & 3.3 & 4.2 \\
\hline 1999 & .2 & .3 & .5 & .2 & .5 & .3 & .5 & .3 & .2 & 1.0 & .4 & .4 & 2.0 & 4.7 & 4.8 & 6.6 & 3.6 \\
\hline & & & & & & & & dustrial & product & on (inde & & & & & & & \\
\hline 1987 & 90.2 & 91.2 & 91.6 & 92.0 & 92.4 & 93.2 & 93.7 & 93.8 & 93.7 & 95.0 & 95.3 & 95.9 & 91.0 & 92.5 & 93.8 & 95.4 & 93.2 \\
\hline 1988 & 95.9 & 96.2 & 96.3 & 96.8 & 96.9 & 97.0 & 97.6 & 98.1 & 97.8 & 98.0 & 98.8 & 99.3 & 96.1 & 96.9 & 97.8 & 98.7 & 97.4 \\
\hline 1989 & 99.8 & 99.0 & 100.0 & 100.2 & 99.6 & 99.4 & 98.4 & 98.8 & 98.6 & 98.2 & 98.6 & 99.0 & 99.6 & 99.7 & 98.6 & 98.6 & 99.1 \\
\hline 1990 & 98.6 & 99.1 & 99.6 & 99.0 & 99.4 & 99.3 & 99.3 & 99.5 & 99.6 & 99.1 & 97.7 & 97.2 & 99.1 & 99.2 & 99.5 & 98.0 & 98.9 \\
\hline 1991 & 96.7 & 95.9 & 95.0 & 95.4 & 96.1 & 97.2 & 97.3 & 97.4 & 98.4 & 98.3 & 98.1 & 97.5 & 95.9 & 96.2 & 97.7 & 98.0 & 97.0 \\
\hline 1992 & 97.6 & 98.1 & 98.9 & 99.7 & 99.9 & 99.7 & 100.5 & 100.2 & 100.7 & 101.2 & 101.8 & 101.7 & 98.2 & 99.8 & 100.5 & 101.6 & 100.0 \\
\hline 1993 & 102.1 & 102.6 & 102.8 & 103.2 & 102.7 & 103.0 & 103.1 & 102.9 & 104.0 & 104.5 & 104.9 & 105.6 & 102.5 & 103.0 & 103.3 & 105.0 & 103.4 \\
\hline 1994 & 105.9 & 106.1 & 107.0 & 107.6 & 108.5 & 109.2 & 109.5 & 110.1 & 110.3 & 110.9 & 111.6 & 112.7 & 106.3 & 108.4 & 110.0 & 111.8 & 109.1 \\
\hline 1995 & 113.3 & 113.2 & 113.4 & 113.3 & 113.8 & 114.3 & 113.8 & 115.1 & 115.6 & 115.5 & 115.8 & 115.9 & 113.3 & 113.8 & 114.9 & 115.7 & 114.4 \\
\hline 1996 & 115.6 & 116.9 & 116.6 & 118.0 & 119.0 & 119.8 & 119.9 & 120.7 & 121.2 & 121.2 & 122.1 & 122.4 & 116.4 & 118.9 & 120.6 & 121.9 & 119.4 \\
\hline 1997 & 123.0 & 124.0 & 124.5 & 125.2 & 125.8 & 126.6 & 127.2 & 128.0 & 128.8 & 129.6 & 130.2 & 130.6 & 123.8 & 125.9 & 128.0 & 130.1 & 127.1 \\
\hline 1998 & 130.9 & 130.7 & 131.1 & 131.7 & 132.4 & 131.5 & 131.3 & 133.6 & 133.5 & 134.1 & 133.8 & 133.8 & 130.9 & 131.9 & 132.8 & 133.9 & 132.4 \\
\hline 1999 & 134.1 & 134.5 & 135.1 & 135.5 & 136.2 & 136.6 & 137.4 & 137.7 & 138.1 & 139.4 & 139.9 & 140.5 & 134.6 & 136.1 & 137.7 & 139.9 & 137.2 \\
\hline & & & & & & & & $\mathrm{Ca}$ & acity (in & lex) & & & & & & & \\
\hline 1987 & 114.0 & 114.1 & 114.2 & 114.3 & 114.4 & 114.5 & 114.6 & 114.7 & 114.9 & 115.0 & 115.1 & 115.2 & 114.1 & 114.4 & 114.7 & 115.1 & 114.6 \\
\hline 1988 & 115.3 & 115.5 & 115.6 & 115.7 & 115.8 & 115.9 & 116.0 & 116.2 & 116.3 & 116.4 & 116.5 & 116.7 & 115.5 & 115.8 & 116.2 & 116.5 & 116.0 \\
\hline 1989 & 116.8 & 117.0 & 117.2 & 117.4 & 117.6 & 117.8 & 118.0 & 118.2 & 118.4 & 118.6 & 118.8 & 119.0 & 117.0 & 117.6 & 118.2 & 118.8 & 117.9 \\
\hline 1990 & 119.2 & 119.3 & 119.5 & 119.7 & 119.9 & 120.1 & 120.2 & 120.4 & 120.6 & 120.8 & 121.0 & 121.2 & 119.3 & 119.9 & 120.4 & 121.0 & 120.2 \\
\hline 1991 & 121.4 & 121.6 & 121.7 & 121.9 & 122.1 & 122.2 & 122.4 & 122.6 & 122.7 & 122.9 & 123.0 & 123.2 & 121.6 & 122.1 & 122.6 & 123.0 & 122.3 \\
\hline 1992 & 123.4 & 123.6 & 123.9 & 124.1 & 124.4 & 124.6 & 124.8 & 125.0 & 125.2 & 125.4 & 125.6 & 125.8 & 123.6 & 124.4 & 125.0 & 125.6 & 124.7 \\
\hline 1993 & 126.0 & 126.2 & 126.4 & 126.6 & 126.8 & 127.0 & 127.3 & 127.5 & 127.7 & 128.0 & 128.3 & 128.6 & 126.2 & 126.8 & 127.5 & 128.3 & 127.2 \\
\hline 1994 & 129.0 & 129.3 & 129.7 & 130.1 & 130.5 & 130.9 & 131.4 & 131.8 & 132.3 & 132.8 & 133.3 & 133.8 & 129.3 & 130.5 & 131.8 & 133.3 & 131.2 \\
\hline 1995 & 134.3 & 134.8 & 135.4 & 135.9 & 136.5 & 137.1 & 137.7 & 138.2 & 138.8 & 139.4 & 140.0 & 140.6 & 134.8 & 136.5 & 138.2 & 140.0 & 137.4 \\
\hline 1996 & 141.2 & 141.9 & 142.5 & 143.2 & 143.9 & 144.6 & 145.2 & 145.8 & 146.4 & 147.0 & 147.6 & 148.2 & 141.9 & 143.9 & 145.8 & 147.6 & 144.8 \\
\hline 1997 & 148.8 & 149.5 & 150.1 & 150.7 & 151.4 & 152.1 & 152.7 & 153.4 & 154.1 & 154.8 & 155.5 & 156.3 & 149.5 & 151.4 & 153.4 & 155.6 & 152.5 \\
\hline 1998 & 157.1 & 158.0 & 158.9 & 159.8 & 160.7 & 161.6 & 162.4 & 163.2 & 163.9 & 164.6 & 165.3 & 166.0 & 158.0 & 160.7 & 163.2 & 165.3 & 161.8 \\
\hline 1999 & 166.7 & 167.4 & 168.0 & 168.6 & 169.2 & 169.8 & 170.2 & 170.7 & 171.2 & 171.7 & 172.3 & 172.8 & 167.3 & 169.2 & 170.7 & 172.3 & 169.9 \\
\hline & & & & & & & & Utilizati & n (level & percent & & & & & & & \\
\hline 1987 & 79.1 & 80.0 & 80.2 & 80.5 & 80.7 & 81.4 & 81.8 & 81.8 & 81.6 & 82.6 & 82.8 & 83.2 & 79.8 & 80.8 & 81.7 & 82.9 & 81.3 \\
\hline 1988 & 83.2 & $\begin{array}{l}\text { ou. } \\
83.4\end{array}$ & $\begin{array}{l}\text { ou.2 } \\
83.3\end{array}$ & $\begin{array}{l}\text { ou.J } \\
83.7\end{array}$ & $\begin{array}{l}00.1 \\
83.7\end{array}$ & $\begin{array}{l}01.4 \\
83.6\end{array}$ & $\begin{array}{l}01.0 \\
84.1\end{array}$ & $\begin{array}{l}01.0 \\
84.5\end{array}$ & $\begin{array}{l}01.0 \\
84.1\end{array}$ & $\begin{array}{l}02.0 \\
84.2\end{array}$ & $\begin{array}{l}02.0 \\
84.8\end{array}$ & $\begin{array}{l}05.2 \\
85.1\end{array}$ & 83.3 & $\begin{array}{l}00.0 \\
83.7\end{array}$ & 84.2 & 84.7 & 84.0 \\
\hline 1989 & 85.4 & 84.6 & 85.3 & 85.3 & 84.7 & 84.4 & 83.4 & 83.6 & 83.3 & 82.8 & 83.0 & 83.2 & 85.1 & 84.8 & 83.4 & 83.0 & 84.1 \\
\hline 1990 & 82.7 & 83.0 & 83.3 & 82.7 & 82.9 & 82.7 & 82.6 & 82.6 & 82.6 & 82.0 & 80.8 & 80.2 & 83.0 & 82.8 & 82.6 & 81.0 & 82.3 \\
\hline 1991 & 79.6 & 78.9 & 78.1 & 78.2 & 78.7 & 79.6 & 79.5 & 79.5 & 80.2 & 80.0 & 79.8 & 79.2 & 78.9 & 78.8 & 79.7 & 79.6 & 79.3 \\
\hline 1992 & 79.1 & 79.4 & 79.8 & 80.3 & 80.3 & 80.0 & 80.5 & 80.1 & 80.4 & 80.7 & 81.0 & 80.8 & 79.4 & 80.2 & 80.3 & 80.8 & 80.2 \\
\hline 1993 & 81.0 & 81.3 & 81.3 & 81.5 & 81.0 & 81.1 & 81.0 & 80.7 & 81.4 & 81.6 & 81.7 & 82.1 & 81.2 & 81.2 & 81.0 & 81.8 & 81.3 \\
\hline 1994 & 82.1 & 82.0 & 82.5 & 82.7 & 83.1 & 83.4 & 83.4 & 83.5 & 83.4 & 83.6 & 83.8 & 84.2 & 82.2 & 83.1 & 83.4 & 83.9 & 83.1 \\
\hline 1995 & 84.4 & 83.9 & 83.8 & 83.3 & 83.3 & 83.3 & 82.7 & 83.3 & 83.3 & 82.9 & 82.7 & 82.4 & 84.0 & 83.3 & 83.1 & 82.7 & 83.3 \\
\hline 1996 & 81.8 & 82.4 & 81.8 & 82.4 & 82.7 & 82.9 & 82.6 & 82.8 & 82.8 & 82.4 & 82.7 & 82.6 & 82.0 & 82.6 & 82.7 & 82.6 & 82.5 \\
\hline 1997 & 82.6 & 83.0 & 83.0 & 83.1 & 83.1 & 83.2 & 83.3 & 83.4 & 83.6 & 83.7 & 83.7 & 83.5 & 82.9 & 83.1 & 83.4 & 83.7 & 83.3 \\
\hline 1998 & 83.3 & 82.7 & 82.5 & 82.4 & 82.4 & 81.3 & 80.8 & 81.9 & 81.5 & 81.5 & 80.9 & 80.6 & 82.8 & 82.1 & 81.4 & 81.0 & 81.8 \\
\hline 1999 & 80.4 & 80.4 & 80.5 & 80.4 & 80.5 & 80.5 & 80.7 & 80.7 & 80.6 & 81.2 & 81.2 & 81.3 & 80.4 & 80.5 & 80.7 & 81.2 & 80.7 \\
\hline
\end{tabular}

Note. Monthly percentage change figures show change from the previous month; quarterly figures show the change from the previous quarter at a compound annual rate of growth. Production and capacity indexes are expressed as percentages of output in 1992.
Estimates from October 1999 through December 1999 are subject to further revision in the upcoming monthly releases.

1. Annual averages of industrial production are calculated from indexes that are not seasonally adjusted. 
A.2. Revised data for industrial production, capacity, and utilization for manufacturing industries, 1987-99 Seasonally adjusted data except as noted

\begin{tabular}{|c|c|c|c|c|c|c|c|c|c|c|c|c|c|c|c|c|c|}
\hline \multirow{2}{*}{ Year } & \multirow{2}{*}{ Jan. } & \multirow{2}{*}{ Feb. } & \multirow{2}{*}{ Mar. } & \multirow{2}{*}{ Apr. } & \multirow{2}{*}{ May } & \multirow{2}{*}{ June } & \multirow{2}{*}{ July } & \multirow{2}{*}{ Aug. } & \multirow{2}{*}{ Sept. } & \multirow{2}{*}{ Oct. } & & & & $\mathrm{Qu}$ & rter & & \\
\hline & & & & & & & & & & & Nov. & Dec. & 1 & 2 & 3 & 4 & avg. ${ }^{1}$ \\
\hline & & & & & & & Indust & al produ & tion (pe & centage & change) & & & & & & \\
\hline 1987 & -.8 & 1.6 & .2 & .5 & .3 & 1.0 & .7 & -.2 & .1 & 1.3 & .5 & .6 & 5.0 & 7.0 & 5.5 & 7.6 & 5.3 \\
\hline 1988 & -.2 & .4 & -.1 & 1.0 & -.1 & .0 & .7 & .3 & .2 & .2 & .9 & 6 & 2.3 & 4.1 & 3.7 & 5.2 & 4.7 \\
\hline 1989 & .9 & -1.2 & .8 & .1 & -.7 & .0 & -1.1 & .3 & -.3 & -.6 & .4 & .1 & 4.3 & -.7 & -4.5 & -1.4 & 1.9 \\
\hline 1990 & -.2 & .9 & .3 & -.8 & .4 & -.1 & .0 & .3 & -.1 & -.6 & -1.3 & -.6 & 2.9 & -.1 & .8 & -6.3 & -.5 \\
\hline 1991 & -.9 & -.7 & -1.1 & .3 & .7 & 1.4 & .2 & .2 & 1.1 & -.1 & -.2 & -.5 & -9.7 & 1.2 & 7.8 & 1.7 & -2.4 \\
\hline 1992 & .2 & .8 & .9 & .7 & .4 & .0 & .7 & -.2 & .4 & .5 & 6 & -.2 & 2.3 & 7.3 & 3.5 & 3.9 & 4.0 \\
\hline 1993 & .7 & .2 & 3 & .5 & -.4 & .1 & .1 & -.4 & 1.3 & .4 & .5 & .8 & 4.2 & 2.4 & .8 & 7.1 & 3.7 \\
\hline 1994 & .0 & .2 & 1.1 & .8 & 1.0 & .4 & .5 & .7 & .3 & .7 & .8 & .9 & 5.2 & 10.0 & 6.7 & 8.0 & 6.1 \\
\hline 1995 & .7 & -.3 & .3 & -.2 & .3 & 6 & -.6 & 1.1 & .8 & -.1 & .1 & .0 & 6.1 & 1.4 & 3.3 & 3.6 & 5.3 \\
\hline 1996 & -.3 & 1.1 & -.4 & 1.4 & .9 & .8 & .4 & .7 & .5 & -.1 & .8 & .4 & 1.6 & 9.9 & 7.7 & 4.6 & 4.7 \\
\hline 1997 & .4 & 1.0 & .5 & .5 & .5 & .8 & .4 & .8 & .6 & .6 & 6 & .4 & 7.1 & 7.4 & 7.8 & 7.4 & 7.3 \\
\hline 1998 & .4 & -.1 & .2 & 6 & .5 & -.8 & -.1 & 2.0 & -.1 & .7 & .0 & .1 & 3.3 & 2.6 & 3.4 & 5.6 & 4.9 \\
\hline 1999 & .1 & .5 & .3 & .3 & .6 & .3 & .4 & .4 & .3 & 1.0 & 6 & .2 & 2.5 & 4.9 & 4.7 & 7.2 & 4.3 \\
\hline & & & & & & & & dustrial & product & on (inde & & & & & & & \\
\hline 1987 & 89.6 & 91.0 & 91.2 & 91.6 & 91.9 & 92.8 & 93.4 & 93.3 & 93.4 & 94.6 & 95.1 & 95.6 & 90.6 & 92.1 & 93.4 & 95.1 & 92.8 \\
\hline 1988 & 95.4 & 95.8 & 95.7 & 96.7 & 96.6 & 96.6 & 97.3 & 97.5 & 97.7 & 97.9 & 98.9 & 99.4 & 95.6 & 96.6 & 97.5 & 98.7 & 97.1 \\
\hline 1989 & 100.3 & 99.1 & 99.9 & 100.0 & 99.4 & 99.4 & 98.3 & 98.7 & 98.4 & 97.8 & 98.2 & 98.3 & 99.8 & 99.6 & 98.5 & 98.1 & 99.0 \\
\hline 1990 & 98.1 & 99.0 & 99.3 & 98.6 & 99.0 & 98.9 & 98.8 & 99.1 & 99.0 & 98.4 & 97.2 & 96.6 & 98.8 & 98.8 & 99.0 & 97.4 & 98.5 \\
\hline 1991 & 95.8 & 95.1 & 94.1 & 94.4 & 95.0 & 96.3 & 96.6 & 96.8 & 97.8 & 97.8 & 97.6 & 97.1 & 95.0 & 95.2 & 97.0 & 97.5 & 96.2 \\
\hline 1992 & 97.2 & 98.0 & 98.8 & 99.5 & 99.9 & 99.9 & 100.6 & 100.4 & 100.8 & 101.3 & 101.9 & 101.7 & 98.0 & 99.8 & 100.6 & 101.6 & 100.0 \\
\hline 1993 & 102.4 & 102.6 & 102.9 & 103.5 & 103.1 & 103.2 & 103.3 & 102.9 & 104.2 & 104.7 & 105.1 & 106.0 & 102.7 & 103.3 & 103.5 & 105.3 & 103.7 \\
\hline 1994 & 106.1 & 106.3 & 107.5 & 108.4 & 109.4 & 109.8 & 110.4 & 111.1 & 111.5 & 112.2 & 113.1 & 114.1 & 106.6 & 109.2 & 111.0 & 113.1 & 110.0 \\
\hline 1995 & 114.9 & 114.6 & 115.0 & 114.8 & 115.1 & 115.7 & 115.0 & 116.3 & 117.2 & 117.1 & 117.2 & 117.3 & 114.8 & 115.2 & 116.2 & 117.2 & 115.8 \\
\hline 1996 & 117.0 & 118.3 & 117.8 & 119.4 & 120.5 & 121.5 & 122.0 & 122.8 & 123.5 & 123.4 & 124.3 & 124.8 & 117.7 & 120.5 & 122.8 & 124.1 & 121.3 \\
\hline 1997 & 125.3 & 126.5 & 127.1 & 127.8 & 128.4 & 129.5 & 130.1 & 131.1 & 131.8 & 132.7 & 133.5 & 134.0 & 126.3 & 128.6 & 131.0 & 133.4 & 130.1 \\
\hline 1998 & 134.5 & 134.3 & 134.5 & 135.3 & 135.9 & 134.8 & 134.7 & 137.4 & 137.3 & 138.3 & 138.3 & 138.4 & 134.5 & 135.3 & 136.5 & 138.3 & 136.4 \\
\hline 1999 & 138.6 & 139.3 & 139.7 & 140.2 & 141.0 & 141.4 & 142.0 & 142.5 & 142.9 & 144.3 & 145.2 & 145.5 & 139.2 & 140.9 & 142.5 & 145.0 & 142.3 \\
\hline & & & & & & & & $\mathrm{Ca}$ & acity (in & dex) & & & & & & & \\
\hline 1987 & 113.2 & 113.4 & 113.6 & 113.8 & 113.9 & 114.1 & 114.2 & 114.4 & 114.6 & 114.7 & 114.9 & 115.0 & 113.4 & 113.9 & 114.4 & 114.9 & 114.1 \\
\hline 1988 & 115.2 & 115.3 & 115.4 & 115.6 & 115.7 & 115.8 & 116.0 & 116.1 & 116.3 & 116.5 & 116.6 & 116.8 & 115.3 & 115.7 & 116.1 & 116.6 & 115.9 \\
\hline 1989 & 117.0 & 117.3 & 117.5 & 117.8 & 118.0 & 118.3 & 118.5 & 118.7 & 119.0 & 119.2 & 119.5 & 119.7 & 117.3 & 118.0 & 118.7 & 119.5 & 118.4 \\
\hline 1990 & 119.9 & 120.1 & 120.3 & 120.5 & 120.7 & 120.9 & 121.1 & 121.3 & 121.5 & 121.7 & 122.0 & 122.2 & 120.1 & 120.7 & 121.3 & 122.0 & 121.0 \\
\hline 1991 & 122.4 & 122.6 & 122.8 & 123.0 & 123.1 & 123.3 & 123.5 & 123.7 & 123.8 & 124.0 & 124.2 & 124.3 & 122.6 & 123.1 & 123.7 & 124.2 & 123.4 \\
\hline 1992 & 124.6 & 124.8 & 125.1 & 125.4 & 125.6 & 125.9 & 126.1 & 126.4 & 126.6 & 126.8 & 127.1 & 127.3 & 124.8 & 125.6 & 126.4 & 127.1 & 126.0 \\
\hline 1993 & 127.5 & 127.7 & 127.9 & 128.2 & 128.4 & 128.6 & 128.9 & 129.1 & 129.4 & 129.7 & 130.0 & 130.4 & 127.7 & 128.4 & 129.1 & 130.0 & 128.8 \\
\hline 1994 & 130.7 & 131.1 & 131.6 & 132.0 & 132.5 & 133.0 & 133.4 & 133.9 & 134.5 & 135.0 & 135.6 & 136.1 & 131.2 & 132.5 & 133.9 & 135.6 & 133.3 \\
\hline 1995 & 136.7 & 137.3 & 138.0 & 138.6 & 139.3 & 140.0 & 140.6 & 141.2 & 141.9 & 142.5 & 143.2 & 143.9 & 137.3 & 139.3 & 141.2 & 143.2 & 140.3 \\
\hline 1996 & 144.6 & 145.4 & 146.1 & 146.9 & 147.7 & 148.5 & 149.2 & 149.9 & 150.6 & 151.3 & 152.0 & 152.7 & 145.4 & 147.7 & 149.9 & 152.0 & 148.7 \\
\hline 1997 & 153.4 & 154.1 & 154.9 & 155.6 & 156.4 & 157.2 & 157.9 & 158.7 & 159.5 & 160.3 & 161.2 & 162.1 & 154.1 & 156.4 & 158.7 & 161.2 & 157.6 \\
\hline 1998 & 163.0 & 164.0 & 165.0 & 166.1 & 167.1 & 168.2 & 169.1 & 170.0 & 170.8 & 171.7 & 172.5 & 173.3 & 164.0 & 167.1 & 170.0 & 172.5 & 168.4 \\
\hline 1999 & 174.1 & 174.8 & 175.5 & 176.2 & 176.9 & 177.6 & 178.2 & 178.7 & 179.3 & 179.9 & 180.5 & 181.2 & 174.8 & 176.9 & 178.7 & 180.6 & 177.8 \\
\hline & & & & & & & & Utilizati & n (leve & percent & & & & & & & \\
\hline 1987 & 79.1 & 80.2 & 80.3 & 80.6 & 80.7 & 81.4 & 81.8 & 81.5 & 81.5 & 82.5 & 82.8 & 83.1 & 79.9 & 80.9 & 81.6 & 82.8 & 81.3 \\
\hline 1988 & 82.9 & 83.1 & 82.9 & 83.7 & 83.5 & 83.4 & 83.8 & 84.0 & 84.0 & 84.1 & 84.8 & 85.1 & 83.0 & 83.5 & 83.9 & 84.7 & 83.8 \\
\hline 1989 & 85.7 & 84.5 & 85.0 & 85.0 & 84.2 & 84.1 & 83.0 & 83.1 & 82.7 & 82.1 & 82.2 & 82.1 & 85.1 & 84.4 & 82.9 & 82.1 & 83.6 \\
\hline 1990 & 81.8 & 82.5 & 82.6 & 81.8 & 82.0 & 81.8 & 81.6 & 81.7 & 81.5 & 80.9 & 79.7 & 79.0 & 82.3 & 81.9 & 81.6 & 79.9 & 81.4 \\
\hline 1991 & 78.2 & 77.5 & 76.6 & 76.8 & 77.1 & 78.1 & 78.2 & 78.2 & 79.0 & 78.9 & 78.6 & 78.1 & 77.5 & 77.3 & 78.5 & 78.5 & 77.9 \\
\hline 1992 & 78.0 & 78.5 & 79.0 & 79.4 & 79.5 & 79.3 & 79.8 & 79.5 & 79.6 & 79.9 & 80.2 & 79.9 & 78.5 & 79.4 & 79.6 & 80.0 & 79.4 \\
\hline 1993 & 80.3 & 80.4 & 80.5 & 80.7 & 80.3 & 80.2 & 80.2 & 79.7 & 80.5 & 80.7 & 80.9 & 81.3 & 80.4 & 80.4 & 80.1 & 81.0 & 80.5 \\
\hline 1994 & 81.1 & 81.1 & 81.7 & 82.1 & 82.6 & 82.6 & 82.7 & 82.9 & 82.9 & 83.1 & 83.4 & 83.8 & 81.3 & 82.4 & 82.9 & 83.4 & 82.5 \\
\hline 1995 & 84.0 & 83.4 & 83.3 & 82.8 & 82.6 & 82.7 & 81.8 & 82.3 & 82.6 & 82.2 & 81.9 & 81.5 & 83.6 & 82.7 & 82.3 & 81.8 & 82.6 \\
\hline 1996 & 80.9 & 81.4 & 80.6 & 81.3 & 81.6 & 81.8 & 81.8 & 81.9 & 82.0 & 81.6 & 81.8 & 81.7 & 80.9 & 81.6 & 81.9 & 81.7 & 81.5 \\
\hline 1997 & 81.7 & 82.1 & 82.1 & 82.1 & 82.1 & 82.4 & 82.4 & 82.6 & 82.7 & 82.8 & 82.8 & 82.6 & 81.9 & 82.2 & 82.5 & 82.7 & 82.4 \\
\hline 1998 & 82.5 & 81.9 & 81.5 & 81.5 & 81.3 & 80.1 & 79.7 & 80.8 & 80.4 & 80.5 & 80.2 & 79.9 & 82.0 & 81.0 & 80.3 & 80.2 & 80.9 \\
\hline 1999 & 79.6 & 79.7 & 79.6 & 79.5 & 79.7 & 79.6 & 79.7 & 79.7 & 79.7 & 80.2 & 80.4 & 80.3 & 79.6 & 79.6 & 79.7 & 80.3 & 79.8 \\
\hline
\end{tabular}


A.3. Rates of growth in industrial production, by major market group, 1995-99

\begin{tabular}{|c|c|c|c|c|c|c|c|c|c|c|}
\hline \multirow[t]{2}{*}{ Market group } & \multicolumn{5}{|c|}{$\begin{array}{l}\text { Revised growth rate } \\
\text { (percent) }\end{array}$} & \multicolumn{5}{|c|}{$\begin{array}{l}\text { Difference between growth rates: } \\
\text { revised less earlier } \\
\text { (percentage points) }\end{array}$} \\
\hline & 1995 & 1996 & 1997 & 1998 & 1999 & 1995 & 1996 & 1997 & 1998 & 1999 \\
\hline Total index & 3.5 & 5.3 & 6.8 & 2.9 & 4.5 & .0 & .0 & .2 & 1.0 & .9 \\
\hline Products, total .. & 1.9 & 4.3 & 5.2 & 2.5 & 3.1 & -.1 & .0 & .1 & .4 & .7 \\
\hline Final products ..... & 2.4 & 4.4 & 5.7 & 2.3 & 3.2 & -.2 & .1 & .1 & .3 & .9 \\
\hline Consumer goods & 1.6 & 2.0 & 2.8 & -.9 & 2.9 & .3 & $\begin{array}{l}.1 \\
-.2\end{array}$ & .1 & -.5 & .5 \\
\hline Durable ................... & $\begin{array}{l}1.0 \\
1.6\end{array}$ & 1.8 & 5.5 & 5.0 & 7.2 & 1.3 & $\begin{array}{l}-.2 \\
-.5\end{array}$ & -1.0 & .1 & .1 \\
\hline Automotive products & $\begin{array}{r}1.0 \\
-3.3\end{array}$ & $\begin{array}{l}1.0 \\
2.4\end{array}$ & 10.3 & 4.7 & 2.9 & $\begin{array}{l}1.3 \\
-.8\end{array}$ & .4 & $\begin{array}{r}-1.0 \\
1.0\end{array}$ & .8 & $\begin{array}{rll}.1 \\
-.1 & & 0\end{array}$ \\
\hline Autos and trucks .. & -6.3 & 2.5 & 13.0 & 4.2 & 1.9 & -1.6 & .0 & .7 & 1.2 & -.2 \\
\hline Autos .......... & -12.8 & -6.2 & 3.6 & 2.7 & -6.1 & -5.6 & -2.4 & .2 & 2.0 & -2.2 \\
\hline Trucks ….................. & .2 & 9.2 & 19.1 & 5.0 & 6.1 & -1.1 & 1.1 & 3.5 & .0 & .9 \\
\hline Auto parts and allied goods & 2.4 & 2.2 & 5.9 & 6.0 & 4.1 & $\begin{array}{r}-1.1 \\
.6\end{array}$ & 1.1 & 1.3 & -.1 & .0 \\
\hline Other durable goods .......... & 5.5 & 1.3 & 1.8 & 5.1 & 11.1 & 3.0 & -1.2 & -2.5 & -.6 & .5 \\
\hline Appliances and electronics $\ldots . . . .$. & 19.2 & 4.1 & 1.4 & 23.8 & 28.6 & 10.3 & -4.8 & -10.4 & 4.3 & -.3 \\
\hline Appliances and air conditioning & -2.1 & -.9 & -2.2 & 9.8 & 3.1 & -.1 & -.7 & -1.7 & -1.5 & -1.0 \\
\hline Home electronics . ............ & 42.3 & 9.4 & 5.6 & 39.4 & 66.1 & 22.2 & -8.9 & -18.6 & 11.6 & 9.4 \\
\hline Carpeting and furniture & -3.0 & 3.1 & 3.0 & 2.5 & 6.5 & .0 & .1 & .6 & -1.1 & 1.5 \\
\hline Miscellaneous ......... & .9 & -1.3 & 1.8 & -3.3 & 4.2 & -.2 & .5 & .9 & -2.0 & 1.5 \\
\hline Nondurable ......... & 1.6 & $\begin{array}{r}-1.3 \\
2.0\end{array}$ & $\begin{array}{l}1.8 \\
2.1\end{array}$ & -2.5 & $\begin{array}{l}4.2 \\
1.7\end{array}$ & .0 & -.2 & .4 & $\begin{array}{r}-2.0 \\
-.7\end{array}$ & .7 \\
\hline Non-energy ............. & $\begin{array}{r}1.0 \\
.9\end{array}$ & 1.9 & 2.1 & -2.3 & 1.1 & .0 & -.2 & .4 & -.7 & 1.2 \\
\hline Foods and tobacco & -.2 & 1.2 & 2.2 & -1.3 & .6 & .2 & -.2 & .9 & -1.9 & 1.2 \\
\hline Clothing ........... & -3.9 & -.4 & -2.4 & -8.1 & -1.6 & -.4 & -.2 & -.3 & -2.4 & 4.6 \\
\hline Chemical products & 5.0 & 4.8 & 2.4 & $\begin{array}{l}0.1 \\
-.2\end{array}$ & 3.0 & -.1 & -.1 & -.4 & 2.2 & .8 \\
\hline Paper products .... & 1.8 & 1.4 & 4.6 & -5.4 & 1.4 & -.3 & -.4 & .7 & -.6 & -.6 \\
\hline Energy products .. & 6.4 & 2.5 & 1.8 & -3.9 & 6.4 & .1 & .1 & .3 & -.4 & -2.2 \\
\hline Fuels .......... & 1.5 & 3.6 & 1.8 & -.6 & $\begin{array}{r}0.4 \\
.5\end{array}$ & .1 & .1 & .1 & .0 & -.6 \\
\hline Utilities .... & 8.7 & $\begin{array}{l}3.0 \\
2.0\end{array}$ & $\begin{array}{l}1.8 \\
1.6\end{array}$ & -5.1 & 9.0 & $\begin{array}{l}.1 \\
.1\end{array}$ & $\begin{array}{l}.1 \\
.2\end{array}$ & .12 & $\begin{array}{r}.0 \\
-.3\end{array}$ & $\begin{array}{r}-.6 \\
-3.8\end{array}$ \\
\hline Equipment, total ...... & 3.7 & 8.6 & 10.3 & 7.3 & 3.7 & -.9 & .6 & -.1 & 1.6 & 1.4 \\
\hline 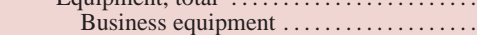 & 5.7 & $\begin{array}{r}0.0 \\
10.8\end{array}$ & 12.8 & 10.0 & 5.0 & -1.3 & 1.0 & -.3 & 1.7 & 1.7 \\
\hline $\begin{array}{l}\text { Information processing and related } \\
\text { Int }\end{array}$ & 12.2 & 18.5 & 16.0 & 20.0 & 22.5 & $\begin{array}{l}-1.5 \\
-2.8\end{array}$ & 2.0 & -.2 & $\begin{array}{l}1.1 \\
5.6\end{array}$ & 3.8 \\
\hline Computer and office ............... & 31.8 & 53.5 & 32.2 & 77.7 & 51.7 & $\begin{array}{r}-12.9 \\
-12.9\end{array}$ & 11.6 & -11.5 & 23.0 & 18.2 \\
\hline Industrial .............. & 8.4 & 1.1 & 4.8 & .7 & -2.6 & -.1 & -.1 & -.3 & -.8 & -1.7 \\
\hline Transit .............. & -10.9 & 15.8 & 21.7 & 10.7 & -12.9 & -1.4 & 1.5 & -1.1 & -1.4 & .4 \\
\hline Autos and trucks & -8.2 & -3.7 & 11.7 & 6.4 & -6 & -2.2 & -.7 & -.6 & 1.3 & -1.5 \\
\hline Other .................... & 2.0 & 6.0 & 10.7 & -1.6 & -7.8 & .1 & .5 & .3 & $\begin{array}{ll}-.2 \\
-.2\end{array}$ & .0 \\
\hline Defense and space equipment & -6.4 & -2.5 & -4.0 & -6 & -3.8 & .7 & -1.6 & -.1 & .9 & .5 \\
\hline Oil and gas well drilling ....... & $\begin{array}{r}-0.4 \\
2.6\end{array}$ & 7.8 & 9.6 & -25.3 & $\begin{array}{r}-5.0 \\
5.9\end{array}$ & .2 & .3 & .3 & .0 & -2.0 \\
\hline Manufactured homes .... & $\begin{array}{l}2.0 \\
7.3\end{array}$ & 3.8 & $\begin{array}{l}9.0 \\
8.9\end{array}$ & $\begin{array}{r}-25.3 \\
6.7\end{array}$ & $\begin{aligned} 5.9 \\
-16.5\end{aligned}$ & -1.3 & $\begin{array}{r}.3 \\
4.4\end{array}$ & 9.6 & -2.4 & $\begin{array}{r}-2.0 \\
1.2\end{array}$ \\
\hline Intermediate products .. & .5 & 3.8 & 3.6 & 3.0 & 2.8 & .0 & .0 & .3 & .6 & .1 \\
\hline Construction supplies & -.4 & 5.8 & 2.8 & 5.6 & 3.8 & -.1 & .0 & .4 & .5 & -.6 \\
\hline Business supplies .... & 1.1 & 2.4 & 4.1 & 1.4 & 2.1 & .0 & .0 & .3 & .7 & .5 \\
\hline Materials ... & 6.0 & 6.9 & 9.2 & 3.5 & 6.8 & .3 & .0 & .2 & 1.9 & 1.4 \\
\hline Durable .............. & 11.4 & 10.6 & 14.3 & 7.3 & 9.3 & .4 & .4 & 1.0 & 3.5 & 2.0 \\
\hline Consumer parts & 3.0 & 1.8 & 9.5 & -2.8 & 5.9 & -6 & .6 & 2.2 & -1.4 & .5 \\
\hline Equipment parts $\ldots \ldots \ldots \ldots \ldots \ldots \ldots \ldots$ & 28.2 & 23.4 & 26.5 & 22.2 & 20.1 & 1.9 & .7 & .1 & 10.3 & 6.4 \\
\hline Semiconductors, printed circuit boards, & & & & & & & & & & \\
\hline and other electrical components .. & 71.7 & 52.2 & 54.2 & 56.6 & 48.4 & 6.3 & 2.8 & .9 & 26.8 & 12.8 \\
\hline Other $\ldots \ldots \ldots \ldots \ldots \ldots \ldots$ & 2.1 & 4.0 & 6.0 & -.7 & 1.6 & -.3 & .1 & 1.0 & .1 & -1.3 \\
\hline Basic metals & .9 & 4.7 & 5.5 & -5.6 & 4.8 & -.7 & .8 & 1.2 & .1 & -1.3 \\
\hline Nondurable ...... & -2.6 & 3.4 & 4.2 & -2.9 & 4.9 & -.1 & -.3 & -.2 & -.1 & 1.3 \\
\hline Textile .. & -7.2 & 2.3 & 3.1 & -9.5 & -.2 & .0 & -.4 & -.1 & -2.3 & 2.4 \\
\hline Paper ... & -2.8 & 4.3 & 4.6 & -2.6 & 4.6 & .0 & -.1 & -.2 & .0 & $\begin{array}{lll}2.4 \\
-.1\end{array}$ \\
\hline Chemical & $\begin{array}{l}-2.8 \\
-1.1\end{array}$ & $\begin{array}{l}4.5 \\
4.6\end{array}$ & $\begin{array}{l}4.0 \\
4.4\end{array}$ & $\begin{array}{l}-2.0 \\
-3.5\end{array}$ & $\begin{array}{l}4.0 \\
8.1\end{array}$ & $\begin{array}{r}.0 \\
-.2\end{array}$ & $\begin{array}{l}-1 \\
-.5\end{array}$ & $\begin{array}{l}-.2 \\
-.6\end{array}$ & .0 & 3.0 \\
\hline Other ... & -3.0 & .6 & 4.3 & 1.6 & 1.3 & -.1 & .1 & .5 & .3 & -.9 \\
\hline Energy .... & .7 & .0 & .1 & -1.0 & .2 & .1 & -.1 & -.2 & -.3 & -1.0 \\
\hline Primary ........... & .4 & -9 & -.1 & -.4 & -.4 & .1 & -.2 & -.3 & -.5 & -1.1 \\
\hline Converted fuel & 1.2 & 3.7 & .4 & -2.2 & 1.4 & .1 & .1 & -.1 & .0 & -.6 \\
\hline \multirow{2}{*}{\multicolumn{11}{|c|}{ Special aggregates }} \\
\hline Total excluding: & & & & & & & & & & \\
\hline Autos and trucks $\ldots \ldots \ldots$ & 3.9 & 5.5 & 6.6 & 2.8 & 4.6 & .1 & .1 & .2 & 1.0 & 1.0 \\
\hline Motor vehicles and parts & 3.8 & 5.7 & 6.4 & 3.0 & 4.5 & .1 & .1 & .1 & 1.0 & 1.0 \\
\hline Computers $\ldots \ldots \ldots \ldots \ldots \ldots$ & 2.9 & 4.6 & 6.3 & 1.5 & 3.3 & .0 & .0 & .4 & .7 & .5 \\
\hline Computers and semiconductors ${ }^{1}$. & 1.0 & 3.0 & 4.7 & -.1 & 1.8 & -.1 & .0 & .5 & -.1 & .1 \\
\hline \multicolumn{11}{|l|}{ Consumer goods excluding: } \\
\hline Autos and trucks...... & 2.1 & 1.9 & 2.2 & -1.2 & 3.0 & .4 & -.3 & .0 & -.6 & .5 \\
\hline Energy $\ldots \ldots \ldots$ & 1.1 & 1.9 & 2.9 & -.6 & 2.6 & .3 & -.3 & .1 & -.6 & .8 \\
\hline \multicolumn{11}{|l|}{ Business equipment excluding: } \\
\hline $\begin{array}{l}\text { Autos and trucks } \ldots \ldots \ldots \ldots \ldots \ldots \\
\text {. . . }\end{array}$ & 7.3 & 12.4 & 12.9 & 10.3 & 5.5 & -1.2 & 1.2 & -.3 & 1.8 & 2.0 \\
\hline Computers and office equipment & 3.4 & 7.2 & 10.9 & 4.0 & -.6 & $\begin{array}{r}-1.2 \\
-.4\end{array}$ & .3 & .5 & $\begin{array}{l}1.0 \\
-.2\end{array}$ & -.8 \\
\hline Materials excluding: & & & & & & & & & & \\
\hline Energy $\ldots \ldots \ldots$ & 7.2 & 8.5 & 11.4 & 4.5 & 8.2 & .3 & .1 & .3 & 2.5 & 1.9 \\
\hline
\end{tabular}

NoTE. Growth rates are calculated as the percentage change in the seasonally adjusted index from the fourth quarter of the previous year to the fourth quarter calculated from annualized of the year specified. For 1999, the differences between growth rates are third quarter of 1999

1. Semiconductors include related electronic components. 
A.4. Rates of growth in industrial production, by industry group, 1995-99

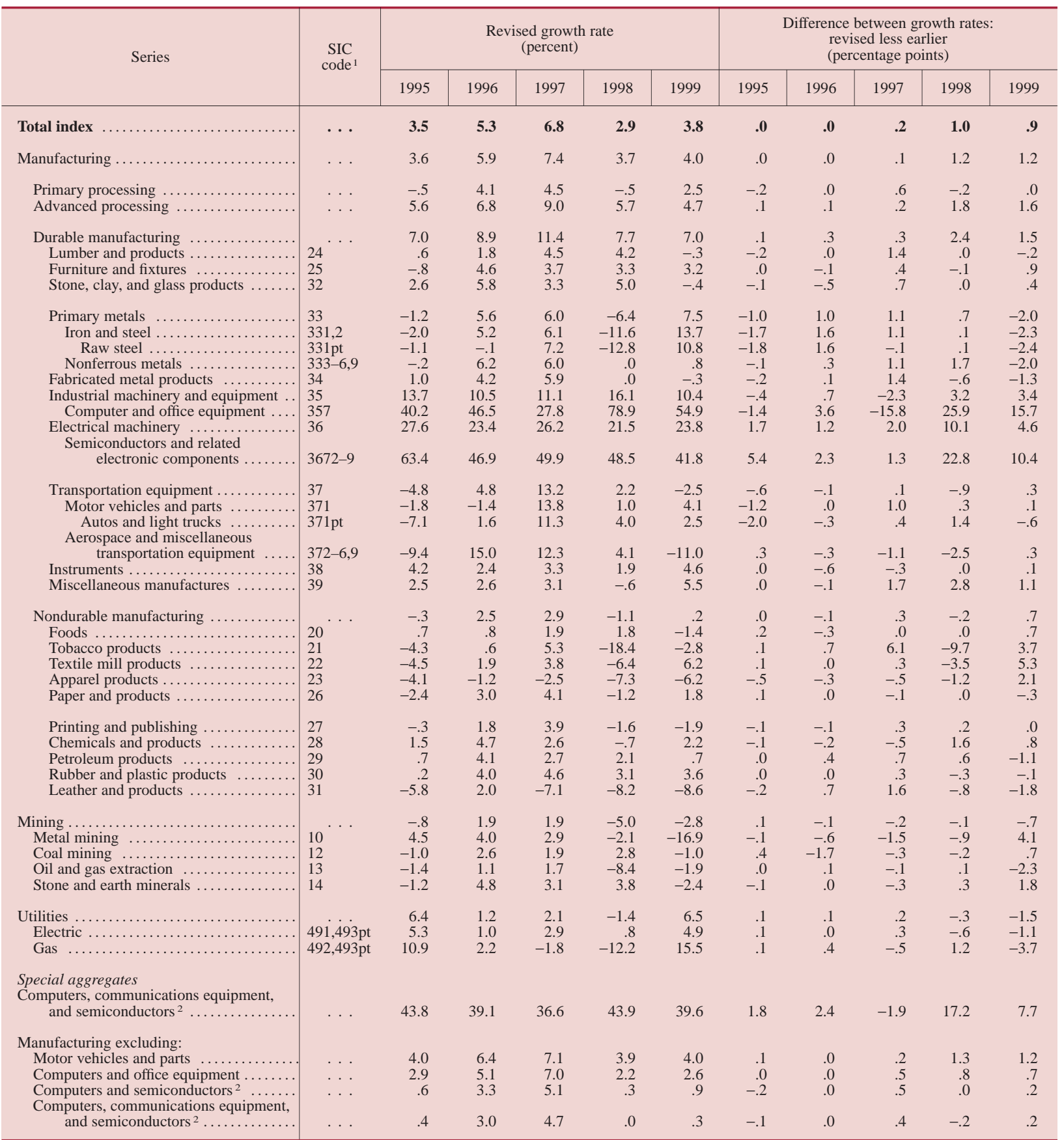

NotE. Growth rates are calculated as the percentage change in the seasonally adjusted index from the fourth quarter of the previous year to the fourth quarter of the year specified. For 1999, the differences between growth rates are calculated from annualized growth rates between the fourth quarter of 1998 and the third quarter of 1999.

Primary-processing manufacturing includes textile mill products; paper and products; industrial chemicals, synthetic materials, and fertilizers; petroleum products; rubber and plastics products; lumber and products; primary metals; fabricated metals; and stone, clay, and glass products. Advanced-processing manufacturing includes foods, tobacco products, apparel products, printing and

publishing, chemical products and other agricultural chemicals, leather and products, furniture and fixtures, industrial and commercial machinery and computer equipment, electrical machinery, transportation equipment, instruments, and miscellaneous manufactures.

1. Standard Industrial Classification; see Executive Office of the President, Office of Management and Budget, Standard Industrial Classification Manual, 1987 (U.S. Government Printing Office, 1987).

2. Semiconductors include related electronic components.

pt Part of classification. 
A.5. Rates of growth in capacity, by industry group, 1995-99

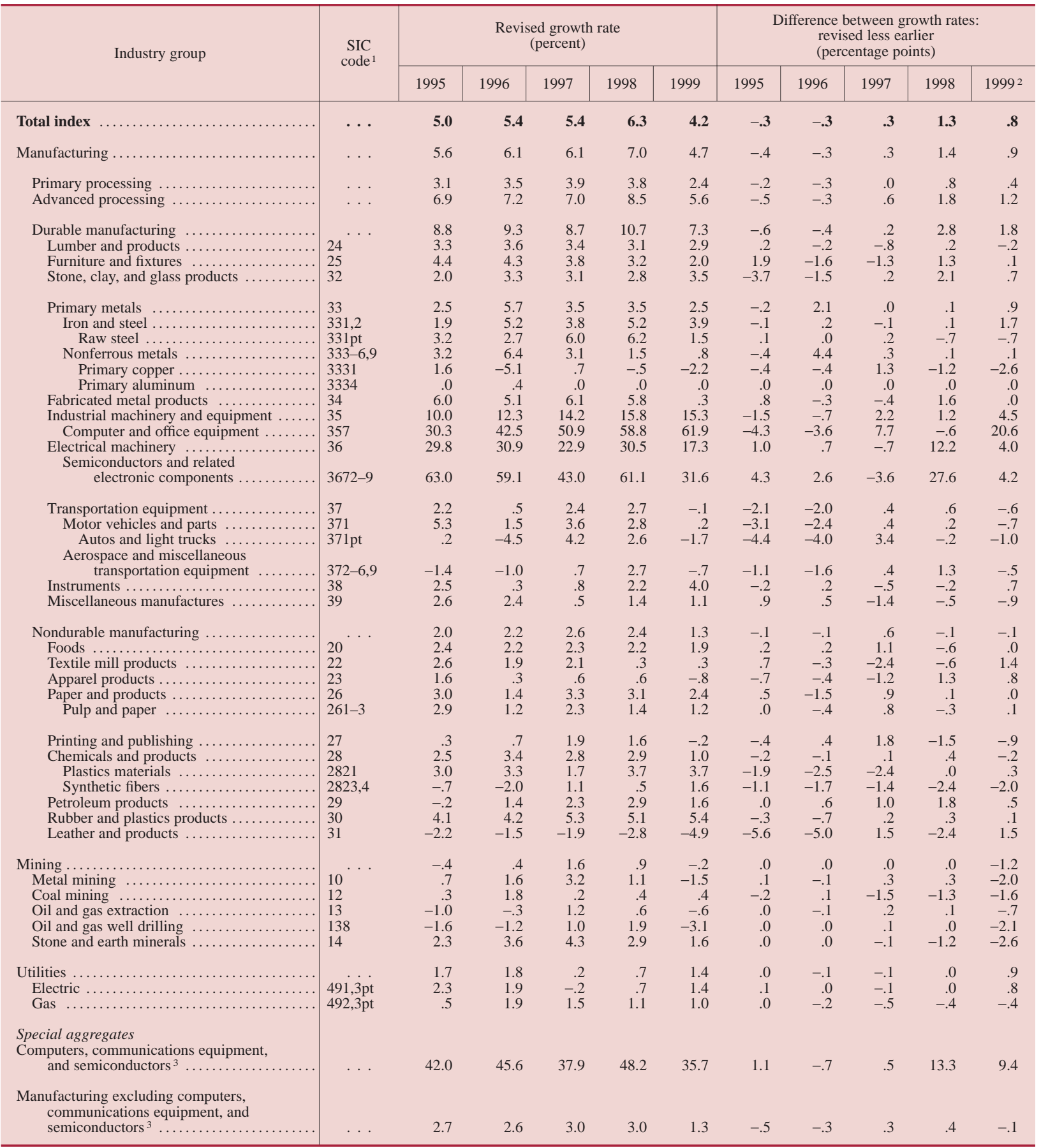

NotE. See general note to table A.4.

1. Standard Industrial Classification; see table A.4, note 1.

3. Semiconductors include related electronic components.

2. Through the fourth quarter of 1999 . 
A.6. Capacity utilization rates, by industry group, 1967-99

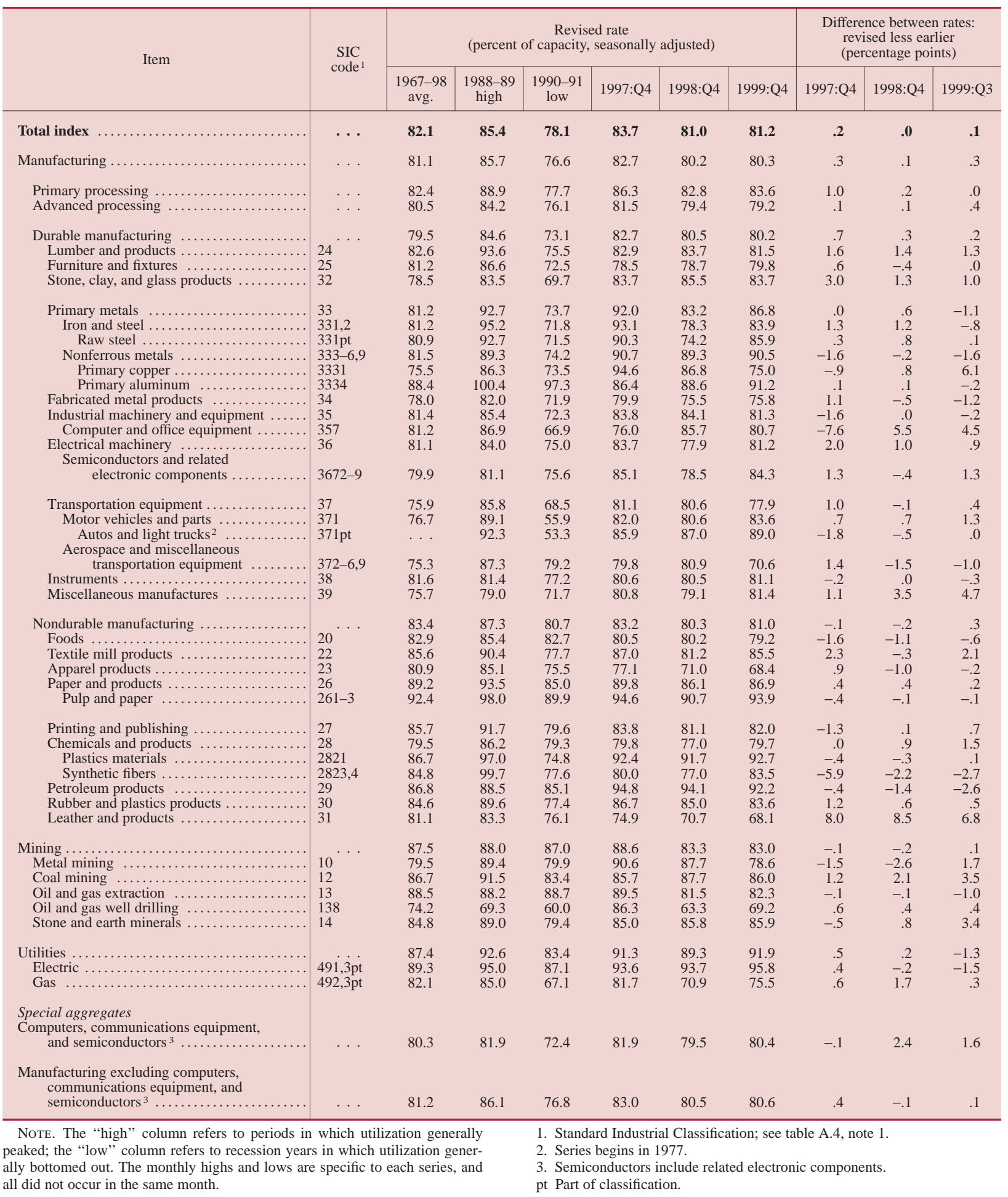


A.7. Annual proportions in industrial production, by industry group, 1991-98

\begin{tabular}{|c|c|c|c|c|c|c|c|c|c|}
\hline Item & $\begin{array}{l}\text { SIC } \\
\operatorname{code}^{1}\end{array}$ & 1991 & 1992 & 1993 & 1994 & 1995 & 1996 & 1997 & 1998 \\
\hline Total index & $\cdots$ & 100.0 & 100.0 & 100.0 & 100.0 & 100.0 & 100.0 & 100.0 & 100.0 \\
\hline Manufacturing & $\cdots$ & 84.5 & 85.4 & 85.9 & 86.7 & 86.8 & 86.8 & 87.8 & 88.6 \\
\hline Primary processing .. & $\ldots$ & 26.1 & 26.6 & 27.0 & 28.2 & 28.0 & 27.6 & 27.8 & 28.0 \\
\hline Advanced processing & $\ldots$ & 58.4 & 58.9 & 58.9 & 58.5 & 58.8 & 59.2 & 60.0 & 60.6 \\
\hline Durable manufacturing & & 44.2 & 44.9 & 45.6 & 46.3 & 46.8 & 47.6 & 48.5 & 49.3 \\
\hline Lumber and products & 24 & 1.8 & 2.1 & 2.2 & 2.2 & 2.1 & 2.1 & 2.1 & 2.1 \\
\hline Furniture and fixtures & 25 & 1.3 & 1.4 & 1.4 & 1.4 & 1.4 & 1.4 & 1.4 & 1.4 \\
\hline Stone, clay, and glass products .... & 32 & 2.1 & 2.1 & 2.1 & 2.2 & 2.2 & 2.3 & 2.4 & 2.4 \\
\hline Primary metals & 33 & 3.1 & 3.1 & 3.3 & 3.5 & 3.5 & 3.5 & 3.6 & 3.6 \\
\hline Iron and steel & 331,2 & 1.7 & 1.8 & 1.9 & 2.0 & 1.9 & 1.9 & 2.0 & 1.9 \\
\hline Raw steel ...... & $331 \mathrm{pt}$ & .1 & .1 & .1 & .1 & .1 & .1 & .1 & .1 \\
\hline Nonferrous metals & $333-6,9$ & 1.4 & 1.4 & 1.4 & 1.6 & 1.6 & 1.6 & 1.6 & 1.7 \\
\hline Fabricated metal products $\ldots \ldots \ldots \ldots$ & 34 & 4.9 & 5.0 & 5.1 & 5.2 & 5.3 & 5.4 & 5.5 & 5.6 \\
\hline Industrial machinery and equipment . & 35 & 7.9 & 7.8 & 8.1 & 8.4 & 8.9 & 9.2 & 9.4 & 10.0 \\
\hline Computer and office equipment .. & 357 & 1.6 & 1.6 & 1.6 & 1.6 & 1.7 & 1.8 & 1.9 & 2.3 \\
\hline Electrical machinery $\ldots \ldots \ldots \ldots . . .$. & 36 & 6.8 & 7.1 & 7.4 & 7.8 & 8.3 & 8.6 & 8.8 & 8.6 \\
\hline $\begin{array}{l}\text { Semiconductors and related } \\
\text { electronic components . }\end{array}$ & $3672-9$ & 2.3 & 2.5 & 2.6 & 2.9 & 3.4 & 3.6 & 3.7 & 3.5 \\
\hline Transportation equipment .. & 37 & 9.6 & 9.4 & 9.5 & 9.3 & 8.9 & 8.8 & 9.2 & 9.4 \\
\hline Motor vehicles and parts . & 371 & 4.6 & 4.7 & 5.1 & 5.5 & 5.4 & 5.2 & 5.3 & 5.1 \\
\hline Autos and light trucks ${ }^{2} \ldots$ & $371 \mathrm{pt}$ & 2.6 & 2.5 & 2.6 & 2.8 & 2.7 & 2.7 & 2.6 & 2.6 \\
\hline $\begin{array}{l}\text { Aerospace and miscellaneous } \\
\text { transportation equipment }\end{array}$ & $372-6,9$ & 5.0 & 4.7 & 4.4 & 3.8 & 3.5 & 36 & 39 & 4.3 \\
\hline Instruments $\ldots \ldots \ldots \ldots \ldots \ldots$ & 38 & 5.4 & $\begin{array}{l}4.1 \\
5.4\end{array}$ & $\begin{array}{l}4.4 \\
5.3\end{array}$ & $\begin{array}{l}5.0 \\
4.9\end{array}$ & 4.8 & 4.9 & 4.8 & 4.9 \\
\hline Miscellaneous manufactures ...... & 39 & 1.3 & 1.3 & 1.3 & 1.3 & 1.3 & 1.4 & 1.4 & 1.3 \\
\hline Nondurable manufacturing & & 40.3 & 40.6 & 40.3 & 40.4 & 40.1 & 39.3 & 39.3 & 39.3 \\
\hline Foods $\ldots \ldots \ldots \ldots \ldots$ & 20 & 9.4 & 9.6 & 9.6 & 9.3 & 9.2 & 9.0 & 8.9 & 9.0 \\
\hline Tobacco products $\ldots \ldots \ldots \ldots$ & 21 & 1.6 & 1.6 & 1.1 & 1.2 & 1.3 & 1.3 & 1.3 & 1.3 \\
\hline Textile mill products..... & 22 & 1.7 & 1.8 & 1.8 & 1.8 & 1.7 & 1.6 & 1.6 & 1.6 \\
\hline Apparel products $\ldots \ldots \ldots \ldots \ldots$ & 23 & 2.2 & 2.2 & 2.1 & 2.1 & 2.0 & 1.9 & 1.8 & 1.7 \\
\hline Paper and products.......... & 26 & 3.7 & 3.5 & 3.4 & 3.8 & 3.9 & 3.5 & 3.5 & 3.5 \\
\hline Printing and publishing . & 27 & 6.8 & 6.8 & 6.8 & 6.6 & 6.6 & 6.6 & 6.7 & 6.8 \\
\hline Chemicals and products & 28 & 9.9 & 10.0 & 9.9 & 10.0 & 9.9 & 9.7 & 9.8 & 9.8 \\
\hline Petroleum products $\ldots \ldots \ldots$. & 29 & 1.5 & 1.4 & 1.5 & 1.6 & 1.5 & 1.6 & 1.6 & 1.6 \\
\hline Rubber and plastics products . ....... & 30 & 3.3 & 3.5 & 3.6 & 3.8 & 3.7 & 3.7 & 3.8 & 3.8 \\
\hline Leather and products $\ldots \ldots \ldots \ldots \ldots$ & 31 & .3 & .3 & .3 & .2 & .2 & .2 & .2 & .2 \\
\hline Mining $\ldots \ldots \ldots \ldots$ & & 7.5 & 6.8 & 6.4 & 6.0 & 6.1 & 6.5 & 5.9 & 5.2 \\
\hline Metal mining $\ldots \ldots \ldots \ldots \ldots \ldots$ & 10 & .5 & .5 & .4 & .5 & .5 & .4 & .4 & .4 \\
\hline Coal mining $\ldots \ldots \ldots \ldots \ldots \ldots \ldots$ & 12 & 1.1 & 1.0 & .9 & .9 & .9 & .9 & .9 & .8 \\
\hline Oil and gas extraction & 13 & 5.3 & 4.7 & 4.4 & 4.0 & 4.1 & 4.6 & 4.1 & 3.4 \\
\hline Stone and earth minerals $\ldots \ldots \ldots \ldots \ldots$ & 14 & .6 & .6 & .6 & .6 & .6 & .6 & .6 & .6 \\
\hline Utilities ... & & 8.0 & 7.8 & 7.7 & 7.4 & 7.1 & 6.7 & 6.3 & 6.3 \\
\hline Electric $\ldots \ldots \ldots \ldots \ldots \ldots$ & $491,3 \mathrm{pt}$ & 6.5 & 6.2 & 6.1 & 5.8 & 5.6 & 5.4 & 5.2 & 5.3 \\
\hline 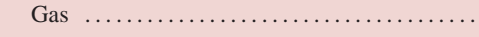 & $492,3 \mathrm{pt}$ & 1.5 & 1.6 & 1.6 & 1.5 & 1.5 & 1.3 & 1.1 & 1.0 \\
\hline \multicolumn{10}{|l|}{ Special aggregates } \\
\hline \multicolumn{10}{|l|}{$\begin{array}{l}\text { Computers, communications equipment, } \\
\text { and semiconductors }{ }^{2} \ldots \ldots \ldots \ldots \ldots\end{array}$} \\
\hline \multicolumn{10}{|l|}{ Manufacturing excluding: } \\
\hline Motor vehicles and parts $\ldots \ldots \ldots$ & $\ldots$ & 80.0 & 80.7 & 80.8 & 81.1 & 81.4 & 81.6 & 82.5 & 83.4 \\
\hline Computers and office equipment . & $\ldots$ & 82.9 & 83.8 & 84.3 & 85.0 & 85.1 & 85.0 & 85.9 & 86.3 \\
\hline Computers and semiconductors ${ }^{2}$ & $\ldots$ & 80.6 & 81.3 & 81.7 & 82.1 & 81.7 & 81.4 & 82.2 & 82.8 \\
\hline $\begin{array}{l}\text { Computers, communications equipment, } \\
\text { and semiconductors }{ }^{2} \ldots \ldots \ldots \ldots \ldots\end{array}$ & $\cdots$ & 79.2 & 79.8 & 80.1 & 80.4 & 80.0 & 79.5 & 80.1 & 80.7 \\
\hline
\end{tabular}

Note. The IP proportion data are estimates of the industries' relative contri-

1. Standard Industrial Classification; see table A.4, note 1 bution to overall IP growth in the following year. For example, a 1 percent Semiconductors include related electronic components. increase in durable goods manufacturing in 1999 would account for a 0.493 perpt Part of classification. 
A.8. Rates of growth in electric power use, 1995-99

\begin{tabular}{|c|c|c|c|c|c|c|c|c|c|c|c|}
\hline \multirow[t]{2}{*}{ Item } & \multirow{2}{*}{$\begin{array}{l}\text { SIC } \\
\text { code }^{1}\end{array}$} & \multicolumn{5}{|c|}{$\begin{array}{l}\text { Revised growth rate } \\
\text { (percent) }\end{array}$} & \multicolumn{5}{|c|}{$\begin{array}{l}\text { Difference between growth rates: } \\
\text { revised less earlier } \\
\text { (percentage points) }\end{array}$} \\
\hline & & 1995 & 1996 & 1997 & 1998 & 1999 & 1995 & 1996 & 1997 & 1998 & 1999 \\
\hline Total & $\cdots$ & -.8 & 1.5 & 1.2 & -.9 & -2.4 & .0 & .1 & .2 & -.6 & 1.0 \\
\hline Manufacturing .. & . . & -.9 & 1.4 & 1.3 & -.9 & -2.5 & .0 & .1 & .2 & -.6 & 1.0 \\
\hline Durable manufacturing & & .5 & -.3 & 4.7 & -1.2 & -.4 & .0 & -.1 & 1.6 & -1.3 & .1 \\
\hline Lumber and products & 24 & 1.5 & 4.1 & 3.4 & 1.7 & 4 & .0 & -.2 & 3.6 & -1.4 & -.8 \\
\hline Furniture and fixtures $\ldots \ldots \ldots$ & 25 & -3.7 & 4.2 & 1.6 & .6 & 3.8 & -.1 & -.1 & .2 & .4 & 1.5 \\
\hline Stone, clay, and glass products & 32 & .2 & 3.5 & 1.5 & 2.6 & -.8 & .0 & .1 & .8 & .0 & 1.3 \\
\hline Primary metals $\ldots \ldots \ldots \ldots \ldots$ & 33 & 1.5 & -3.8 & 6.7 & -3.8 & -.6 & -.1 & .0 & 2.6 & -2.4 & -.4 \\
\hline Fabricated metal products & 34 & .1 & 3.7 & 4.6 & -1.2 & -.8 & .0 & .0 & 1.5 & -.8 & -1.1 \\
\hline Industrial machinery and equipment & 35 & .5 & 1.3 & 4.2 & 1.0 & -2.5 & .1 & -.1 & 1.2 & -2.5 & -1.1 \\
\hline Electrical machinery.......... & 36 & 1.4 & 2.4 & 3.0 & -2.0 & -3.9 & -.1 & -.1 & .7 & -.9 & 1.1 \\
\hline Transportation equipment ... & 37 & -1.9 & -.7 & 5.6 & -.8 & 3.4 & .1 & -.3 & .4 & -.8 & 1.3 \\
\hline Instruments $\ldots \ldots \ldots \ldots \ldots \ldots$ & 38 & .4 & -2.9 & 1.0 & 3.8 & .7 & .0 & -.1 & .4 & 2.2 & 2.6 \\
\hline Miscellaneous manufactures ... & 39 & -4.8 & 7.2 & 2.1 & 8.3 & 2.7 & -.1 & .3 & 1.8 & 6.5 & -6.2 \\
\hline Nondurable manufacturing & & -2.0 & 2.8 & -1.4 & -.7 & -4.1 & .0 & .2 & -.9 & .1 & 1.8 \\
\hline 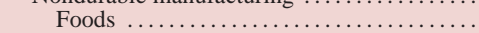 & 20 & 2.5 & 1.7 & 3.3 & 2.3 & -2.9 & .0 & .0 & 1.1 & -.1 & -.2 \\
\hline Tobacco products .. & 21 & 6.4 & .0 & .7 & -1.7 & -6.3 & .1 & .2 & .2 & .0 & -1.5 \\
\hline Textile mill products... & 22 & -3.3 & 2.7 & 3.2 & -1.4 & -2.2 & .0 & -.2 & 1.1 & -3.3 & 1.8 \\
\hline Apparel products .............. & 23 & -6.3 & -1.8 & -1.7 & -3.4 & -9.5 & .0 & .0 & .2 & -1.0 & 1.2 \\
\hline Paper and products ........... & 26 & -.3 & 1.1 & 2.4 & -.8 & -1.1 & .3 & .7 & .2 & .8 & 2.2 \\
\hline Printing and publishing . & 27 & .6 & .8 & 2.9 & 2.2 & -5.4 & -.1 & .0 & -.1 & .3 & -.1 \\
\hline Chemicals and products $\ldots . .$. & 28 & -6.5 & 6.0 & -5.6 & -2.3 & -9.8 & -.1 & .3 & -1.5 & .2 & 2.4 \\
\hline Petroleum products $\ldots \ldots \ldots \ldots$ & 29 & 7.4 & -3.2 & -3.4 & -1.2 & 5.3 & .1 & .1 & -5.9 & 1.8 & 3.8 \\
\hline Rubber and plastics products ... & 30 & -.5 & 3.3 & 1.9 & 3.6 & 1.1 & .0 & -.2 & 1.3 & -1.2 & .1 \\
\hline Leather and products ........ & 31 & -9.3 & -1.5 & -1.3 & -3.8 & -8.4 & -.1 & -.1 & .3 & -.8 & -1.5 \\
\hline Mining ......... & & 1.1 & 3.0 & -.2 & -.6 & -.9 & .0 & .2 & .2 & -.9 & 1.2 \\
\hline Metal mining .... & 10 & 8.3 & 2.6 & .4 & -.1 & -2.8 & -.1 & 1 & -.1 & -.1 & 1.6 \\
\hline Coal mining $\ldots \ldots \ldots \ldots$ & 12 & -1.3 & .0 & .0 & 1.0 & -1.2 & .0 & .0 & .7 & -.6 & 1.1 \\
\hline Oil and gas extraction .. & 13 & -5.0 & 4.5 & 1.5 & -6.6 & 1.8 & .0 & .1 & .5 & -1.3 & -.9 \\
\hline Stone and earth minerals . & 14 & 6.0 & 4.4 & -4.8 & 9.5 & -2.6 & .3 & .7 & -.6 & -2.0 & 4.4 \\
\hline Supplementary groups & & & & & & & & & & & \\
\hline Total, excluding nuclear nondefense & $\ldots$ & .6 & 1.0 & 2.4 & -1.3 & -.4 & .0 & .1 & .2 & -.6 & 1.0 \\
\hline Utilities sales to industry $\ldots \ldots \ldots \ldots$ & & -1.1 & 2.1 & 1.2 & -.8 & -2.3 & .0 & .1 & .2 & -.6 & 1.0 \\
\hline Industrial generation ...... & $\ldots$ & 4.8 & -5.7 & .7 & -1.9 & 3.9 & .0 & .0 & -.1 & -.7 & .7 \\
\hline
\end{tabular}

Note. Growth rates are calculated as the percentage change in the seasonally adjusted index from the fourth quarter of the previous year to the fourth quarter

1. Standard Industrial Classification; see table A.4, note 1 .

of the year specified. For 1999, the growth rates are calculated from the fourth

quarter of 1998 to the third quarter of 1999 and annualized. 